\title{
The white Man's Body ${ }^{1}$
}

\section{Af Hans Bonde}

»Jeg har observeret, at noesten alt fysisk arbejde $i$ Deres land udføres af de indf $\phi d$ te. Dette vil uvagerligt fore til de hvide racers degeneration med mindre de deltager $i$ systematisk fysisk træening «

Niels Bukh ${ }^{2}$

Kort før anden verdenskrigs udbrud den 8. august 1939 rejste den danske gymnastikpædagog Niels Bukh med et hold gymnaster på turné til Sydafrika. Niels Bukh havde under første verdenskrig skabt et nyt gymnastiksystem, som i slutningen af 1920'rne var blevet dominerende i dansk mandsgymnastik. Gennem turneer i Europa, Asien, USA, USSR, Canada og Sydamerika havde han vundet international berømmelse, og var blevet et nationalsymbol, omend et omdiskuteret sådant. For den danske offentlighed var det nemlig klart, at Niels Bukh politisk var ultrahøjreorienteret med affinitet til nazismen. Det bliver derfor væsentligt i denne artikel, at undersøge den »politisering « ${ }^{3}$ som foregik i Sydafrika, specielt vedrørende Niels Bukhs forhold til de meget traditionsbundne og stærkt højreorienterede afrikaanere, efterkommerne af de fra Holland indvanderede boere, men også hans opfattelse af de ikke-hvide befolkningsgrupper i Sydafrika.

I Danmark blev pressens interesse for truppens færden intensiveret omkring Anden verdenskrigs udbrud, idet der var en stærk identifikation med de unge menneskers trængsler med at komme hjem til Danmark. Truppen fik oplysningen om krigens udbrud i starten af turen i byen Worcester, ${ }^{4}$ hvor der bredte sig en bekymret stemning. ${ }^{5}$ Det store spørgsmål var, om truppen kunne komme hjem og i så fald, hvor usikker hjemrejsen gennem Europa ville blive.

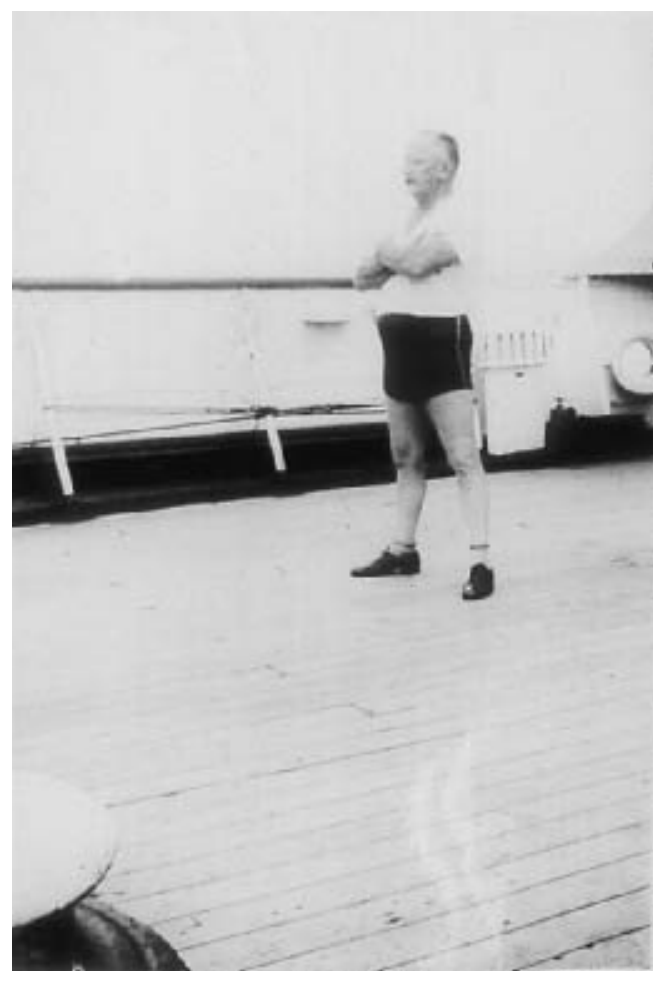

Bukh poserer på dcekket på vej til Sydafri$k a$, privateje (deltagerne Inger J Gunver Fabricius' fotoalbum). 


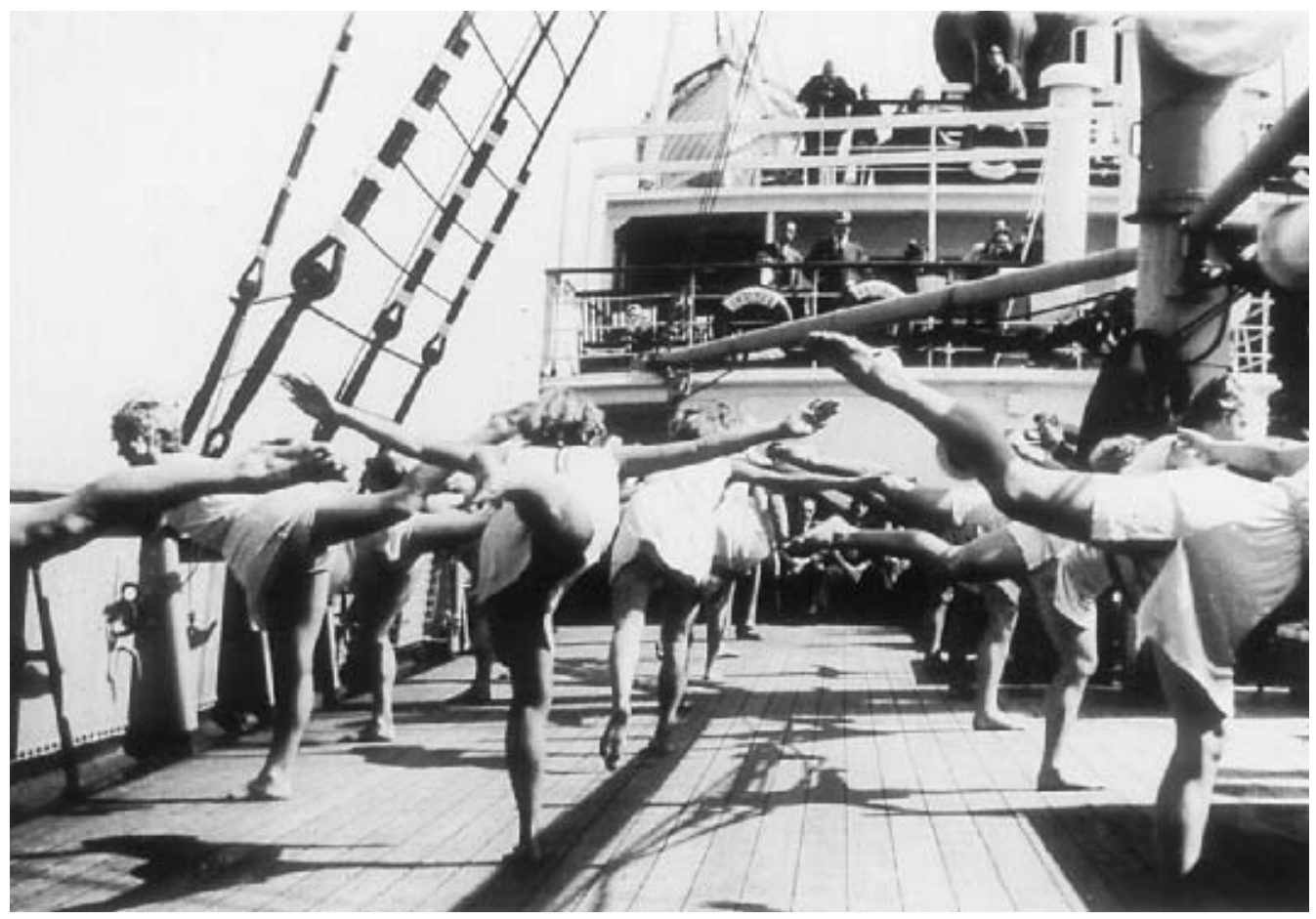

Der tranes på skibsdakket, privateje.

I 1937 havde regeringen Hertzog besluttet at opprioritere breddeidrætten ikke mindst blandt den hvide skoleungdom. De andre racegrupper blev ikke i særlig grad inddraget, ikke mindst fordi kun $1 / 4$ af de sorte børn på dette tidspunkt gik i skole. ${ }^{6}$ På forsiden af turneens officielle program, som blev solgt til opvisningerne, var der en tegning af hvide mandlige og kvindelige gymnaster, som rækker armene og ansigterne op mod himlen og lyset. Indtil da byggede idrætsundervisningen hovedsagelig på den svenske gymnastik uden at være standardiseret. ${ }^{7} 5$ eksperter i fysisk kultur blev sendt til udlandet - især Tyskland - for at søge inspiration til en reform af det sydafrikanske undervisningssystem. Et »Nationalt Råd for Legemsopdragelse « med deltagelse af flere ministre blev dannet, ${ }^{8}$ undervisning i legemsøvelser blev obligatorisk i unionens skoler, ${ }^{9}$ medicinske unders $\emptyset$ gelser af udøvere iværksat, haller bygget, apparatur fremskaffet, og der blev givet statsstøtte til idrætsforeninger. ${ }^{10}$ Hele dette initiativ ville især komme de i forhold til englænderne mindre idrætsaktive afrikaanere til gode.

Der var velkomsthilsener fra flere ledende politikere. Generalguvernør Sir Patrick Duncan tog afsæt i den britiske sports dybe rødder i Sydafrika, idet han håbede, at Niels Bukhs hold ville få lige så stor effekt som andre oversøiske pionerhold indenfor rugby, fodbold, tennis, atletik og boksning. Premierminister Hertzog ønskede i mere generelle vendinger, at truppen ville videregive et positivt indtryk af Sydafrika til den danske befolkning, ikke mindst af sydafrikanernes kærlighed til friluftsliv og »sund amatørsport«. Derudover ledsage- 
des programmet af hilsner fra undervisningsminister H.A. Fagan og forsvarsminister O. Pirow.

Den sydafrikanske presse tog meget positivt imod den danske trup og videregav Rådets idé om, at opvisningerne skulle bruges til at højne den fysiske standard blandt den brede sydafrikanske befolkning, startende med skolebørnene. ${ }^{11}$ Aviserne viste mange billeder af gymnasterne, og fokuserede især på samtidigheden i bevægelserne, mændenes spring og gymnasternes blonde hår. ${ }^{12}$ Viceforsvarsminister Broeksma blev bredt citeret for sin bemærkning om, at: »Vi er forelskede i Danmarks lyshårede piger«. Om opvisningen for 8.000 mennesker i Johannesburg den 22/9 skrev en avis, at: »Barefooted, they marched in perfect unison, their very carriage giving a feeling that there was a body of young people alive and vibrant «. Avisen roste kvinderne for deres »perfectness of the rythm« og mændene for deres »perfect precision of movement. Marionettes could not have moved with such uniformity. Even when one movement ended in a clap of the hands, it was one pistol shot sound, sharp and clear«. Især gjorde de seks mænd i håndstand på plinten og mændenes spring lykke. Det foregik så hurtigt, at de »looked to be a mass of moving limbs«. Publikum forholdt sig i koncentreret stilhed kun afbrudt af klapsalver, når en øvelse sluttede. ${ }^{13}$ En gymnastiklærer, som netop var indvandret fra Holland, overværede opvisningen i Standerton. Han erindrer sig især de smukke rene linjer og den stærke respekt for flaget, som viste sig ved, at en gymnast stod urokkeligt med flaget $\mathrm{i}$ to timer. $^{14}$

Truppens besøg prægedes for det første af, at raceadskillelsen var mærkbar, skønt apartheidsystemet ikke var officielt indført. For det andet eskalerede verdenskri- gen konflikten mellem liberale grupper og de ultrakonservative afrikaanere af hovedsagelig hollandsk afstamning. Afrikaanerne var overvejende konservative, en del endog med sympati for nazismen, mens de engelskorienterede $\mathrm{i}$ hovedsagen var liberale, men ikke af den grund imod racesystemet. En minoritet af afrikaanere var ret liberalt sindede og støttede general Smuts.

Det store spørgsmål var, om unionen skulle forholde sig neutralt eller deltage $\mathrm{i}$ krigen på britisk side, hvilket blev resultatet. Konflikten førte til samlingsregeringen Hertzogs afgang og indsættelse af den britiskvenlige Smutsregering. Hvis Hertzogs anmodning om nyvalg var blevet fulgt af generalguvernør Duncan, ville det have åbnet for stærke konfrontationer mellem neutralistiske afrikaanere og det britiskorienterede befolkningselement. ${ }^{15}$

Den befolkningsgruppe som Bukh og gymnasterne kom tættest på var afrikaanerne. I løbet af 1930'rne, og kulminerende i 1939, var der stærke kræfter, som arbejdede for udviklingen af et stærkt afrikaaner »Volk«med en selvstændig økonomisk, politisk og ideologisk profil. Den afrikaanske »folkelighedsideologi« var inspireret af neo-fichtianske forestillinger om folket som en organisme sammenholdt af en fælles historisk kultur. Ideerne var hentet af afrikaanerideologer i Tyskland gennem 1920'rne. Afrikaanerne sluttede sig sammen i fagforbund, ${ }^{16}$ dannede kooperativer, oprettede banker, og for de unge skabtes der et alternativ til spejderne, den såkaldte Voortrekkerbevægelse. I afrikaanernes vækkelse i slutningen af 30'rne var voortrekkertraditionen helt central, hvilket viste sig i nye monumenter, festdage, folkedanse og bogserier. Initiativerne byggede på de landbrugsorienterede afrikaaneres reaktion mod urbanisering, de engelsktalendes økonomiske overlegenhed og den britiske imperialisme. 
Ledelsen var i hænderne på den hemmelighedsfulde afrikaaner mandeloge $»$ Broederbond $\ll .{ }^{17}$ Bevægelsen byggede på en stærk historiebevidsthed, som forherligede boerforfædrenes, »voortrekkernes« heroiske »trek « ind i det sydlige Afrikas indre og det barske landboliv og sigtede mod at (gen) skabe en »autentisk « afrikaaner folkekultur. I 1938 fejredes 100 året for det store trek med en stærkt symbolladet "genopf $\varnothing$ relse af turen. Hvor folkeligheden i Danmark var led i en med Lorenz Rerups ord »frigørende nationalisme « (med Niels Bukh som én af de markante undtagelser) endte dyrkelsen af afrikaanerne som $»$ volk « med Nationalistpartiets indførsel af apartheidsystemet i 1948.

I det følgende vil der ifølge sydafrikansk tradition blive skelnet mellem »sorte" (som ikke er blandet med andre racer) og »farvede«, som i hovedsagen er en blanding af hvide og sorte arveanlæg.

Kulturmødet mellem Niels Bukhs trup og afrikaanerne står i centrum i denne artikel. Hvilken symbolværdi fik Niels Bukhs gymnastik i den hvide befolkning? Hvilket billede af dansk national identitet og dansk landbokultur fremkom i mødet med afrikaanerne? Indgik turneen i den politiske kamp mellem konservative og liberale hvide?

\section{Sydafrikaturens forl $\phi b$}

I det sydafrikanske undervisningsministeriums officielle årsrapport til regeringen, ${ }^{18}$ blev det efter rejsen vurderet, at 1/8 af Sydafrikas europæiske befolkning, svarende til over en kvart million, og mange »farvede, indere og indfødte « havde overværet de 59 opvisninger. Blandt publikum var der mange skoleelever, studerende og lærere, ${ }^{19}$ som var inviteret af Undervisningsministeriet. Før opvisningerne viste unge, hvide sydafrikanere i reglen gymnastik, boldspil el- ler atletik. ${ }^{20}$ I de 30 byer, hvor truppen gav opvisning, var det faste mønster, at de blev modtaget af en lokal komité og var til reception hos borgmesteren, og »overalt vajede de danske farver ved siden af det sydafrikanske flag «. »Alle opvisningspladser var smykket med det danske flag, og før opvisningen klang den danske nationalsang ud mod gymnasterne, der sænkede vor... fane, medens alle tilskuerne hyldede vort lille land ved at rejse sig op og med blottede hoveder lytte til nationalsangens toner«. Niels Bukh bad ved flere opvisninger om, at også den sydafrikanske nationalsang skulle spilles, men herved rørte han ved kulturkampen mellem afrikaanere og englændere, som henholdsvis ønskede »Die stem van Suid Afrika« og »God Save the King « spillet. De fleste steder blev ingen af de sydafrikanske nationalmelodier spillet »for ikke at give anledning til demonstrationer «. I fald Sydafrikas nationalmelodi skulle synges, blev begge nationalmelodier normalt sunget. ${ }^{21}$ Der var lige så stærk konflikt om flaget som om nationalsangen på dette tidspunkt, men Søgaard nævnede ikke, om det var Union Jack eller Afrikaaner-flaget, som blev anvendt.

Når truppen på dens $13.000 \mathrm{~km}$. lange rejse kørte med toget, havde de deres egne to førsteklasses vogne beregnet til det dobbelte antal passagerer. Med i toget var en boy, der pudsede gymnasternes sko, pressede tøj og redte senge. Ved ankomsten til en by, hvor der skulle gives opvisning, blev vognene koblet fra, hvorefter danskerne ofte blev kørt på byens »mest luxuriøse hotel«. I flere mindre afrikaanerbyer blev deltagerne indkvarteret privat. Især i de større byer blev de modtaget og guidet rundt af bosiddende danskere, som ofte var organiseret i danske foreninger, og som afholdt banketter i anledning af bes $\varnothing$ get.

Truppen rejste gennem alle dele af Syd- 
afrika. Den gav opvisninger i »engelske« kyst- og storbyer og mindre, afrikaansdominerede byer inde i landet. Det blev et fast forl $\varnothing \mathrm{b}$ i de mindre byer, at butikker og skoler blev lukket på opvisningsdagen. De første 3 opvisninger blev afholdt i Stellenbosch den 25. august, efterfulgt af flere opvisninger i det vestlige Cape. Dernæst blev der afholdt opvisninger i Cape Town. Her bestod publikum i Groenpuntserenbaan af mere end 8.000 ikke-hvide, hovedsagelig farvede børn. ${ }^{22}$ I Newlands blev der afholdt opvisning for 12.000 hvide skolebørn. Ved opvisningerne på Newlands rugbystadion citerede den centrale afrikaaneravis Die Burger en tale af J.H. Conradie, som var administrator i Capeprovinsen og et ledende medlem af Broederbond. Han fremhævede, at Bukh havde fået ordner af 3 konger (den danske, svenske og belgiske) og én politiker; Hitler. ${ }^{23}$

Herefter gik rejsen langs østkysten til Port Elisabeth, hvor der blev afholdt to opvisninger for i alt 28.000 mennesker. Efter optræden i East London rejste truppen ind i landet mod Bloemfontein og Kroonstad. Dernæst gik rejsen igen mod kysten nu mod Durban, hvor 20.000 mennesker overværede en opvisning. ${ }^{24}$ Herefter rejste Bukh og gymnasterne påny ind i landet til de to afrikaans provinser Oranje Fristaten og Transvaal. Her blev der sat publikumsrekord, idet der til én enkelt af opvisningerne på Wanders stadion i Johannesburg kom 35.000 tilskuere. Det højeste antal til en opvisning i Bukhgymnastik nogensinde. ${ }^{25}$ Søgaard hævdede, at pressen næste dag meddelte, at det var den største tilskuermængde, der nogensinde havde været samlet til et idrætsstævne i Sydafrika, hvilket kan sammenlignes med, at det $i$ et klassisk værk om sydafrikansk sport nævnes, at rugbys store popularitet i 30'rne viste sig ved, at helt op til 8.000 tilskuere over- værede én af de store kampe mod omkring 1.000 i fodbold. ${ }^{26}$

Truppen bevægede sig derefter mod syd næsten helt til Limpopofloden og Rhodesia og tilbage igen fra Transvaal til Oranje provinsen. I alt besøgtes 28 byer. $^{27}$

På grund af krigsudbruddet efter de første 14 dage blev rejsen forlænget med yderligere 3 uger, hvilket gav Rådet lejlighed til at arrangere en række opvisninger i de byer, som var blevet forbigået i det første program, eller som ønskede endnu en opvisning. De første ti dage gav gymnasterne igen opvisninger i Johannesburg, efterfulgt af bl.a. en opvisning i Bloemfontein. Rejsen afsluttedes med opvisninger i og omkring Cape Town.

\section{Liberale kontra konservative}

Både undervisnings- og forsvarsministeriet var involveret $i$ oprustningen af den fysiske kultur. I det første finansår fra 1938-39 delte Undervisnings- og Forsvarsministeriet bevillingen på $50.000 £$ ligeligt. ${ }^{28}$

De to ministerier var interesseret i opprioriteringen af den fysiske kultur ud fra henholdsvis et liberalt og et stærkt højreorienteret perspektiv. I undervisningsminister M.C. Bothas rapport fra 1938 blev »degenerationen « af de hvide set som et af Sydafrikas væsentligste problemer. ${ }^{29}$ Denne degeneration var et resultat af, at mange hvide anså fysisk arbejde for mindreværdigt, og mente at det helt burde overlades til de ikke-hvide befolkningsgrupper. Dette var ifølge Botha ved at underminere uddannelsessystemet, fordi selv de intellektuelt dårligst udrustede hvide ville have en universitetsuddannelse. Botha citerede en regeringsrapport for, at tendensen kunne føre til at »efterkommerne af denne generation måske vil få store hoveder og underudviklede arme og ben« og konkluderede, 
at Sydafrika fortsat var »et nybyggerland og den ideelle borger bruger sin hjerne, men tøver heller ikke med at smide jakken og gå $\mathrm{i}$ gang med fysisk arbejde. Burde det ikke være et mål for europæeren at kunne arbejde hårdere og bedre end de, som han forventes at lede?

Der var også en angst for at de unge hvides legemlige forfald ville medføre en svækkelse af deres fysiske magt overfor de andre befolkningsgrupper. Når hårde, maskuline idrætsgrene som rugby og boksning var populære i den hvide befolkning, skyldes det uden tvivl en satsning på den hvide mands hårdførhed. I kystbyen East London fortalte de engelske sportslærere truppens medlemmer, at »boksning er en nødvendighed, hvis den hvide mand skal hævde sig overfor den indfødte $\ll{ }^{30}$

Den forsvarsministerielle linje bifaldt degenerationstanken, men havde derudover klare særtræk ikke midst i betoningen af et militært perspektiv. Forsvarsministeriet skulle sørge både for fysisk træning af militære og civile værnegrupper. Forsvarsminister Pirow var én af hovedarkitekterne bag den nye oprustning af kropskulturen. ${ }^{31}$ Pirow var søn af tyske emigranter, men assimileret ind $\mathrm{i}$ afrikaanerbefolkningen. Han var en stærk fortaler for hvid raceoverlegenhed og ivrig dyrker af friluftsliv. Gennem 30'rne beundrede han åbenlyst det tredje rige og afholdt møder med ledende fascistiske statsoverhoveder som Mussolini, Franco, Salazar og Hitler til voldsom irritation for liberale Smutstilhængere som undervisningsminister Hofmeyr. ${ }^{32}$

Ved siden af Pirow var det især viceforsvarsminister A. Broeksma, som agiterede for en ensretning af kropskulturen. Obholzer roste $\mathrm{i}$ en officiel tale truppens opvisning i Cape Times,$^{33}$ og Søgaard kaldte ham for »truppens ven«. Obholzer afviste skarpt liberalisternes påstande om, at der var indført militaristiske metoder indenfor legemskulturen. Hans mål var dog skabelsen af en »energisk nation « ved en individog massedisciplinering af landets ungdom gennem fysisk kultur. Broeksma var imod »de slappe, uordentlige og udisciplinerede vaner, som nu hyldes under betegnelsen frihed og individualisme «. For den almindelige afrikaanerdreng havde $»$ vores meget forhadte militære disciplin « en langt bedre virkning.

Forsvarsministeriets linje viste sig klart i gennemførelsen af et omfattende program for fattige, udisciplinerede afrikaanerdrenge (15-18 år), som organiseredes i den såkaldte »Special-trænings-batallion«. Drengene modtog under militærfolks kontrol håndværksmæssig uddannelse i en flyvemaskinefabrik på Voortrekkerhoogte. Undervisning i legemsøvelser var central og foregik under autoritære former. ${ }^{34}$ Som optakt til Bukhgymnasternes optræden på Newlands rugbystadion i Cape Town holdt et stort hold unge mænd fra Batallionen en opvisning, hvis højdepunkt var, da de med deres kroppe dannede Batallionens symbol SDB, Spesiale Diensbataljon. ${ }^{35}$ Gymnasterne besøgte militærets hovedkvarter og den nationale politiskole i Pretoria, hvor de mødte stor gæstfrihed.

Forsvarsministeriets synspunkter kom især til udtryk ved etableringen af fagbladet »Liggaamsopvoeding «, som blev støttet af Rådet. Redaktøren var Anton Obholzer, som var tysk indvandrer, nazistisk inspireret og gav overmåde stor plads til militærets synspunkter. Obholzer havde været på kursus på Gymnastikhøjskolen i Ollerup, og det var på hans initiativ, at Bukhs hold gav opvisning i Stellenbosch. Obholzers indledende artikel kan ses som et manifest for det nye tidsskrift. Obholzer tegnede omridset af en race- og traditionsba- 
sis for »Et nationalt system for Sydafrika « baseret på landbefolkningens gamle værdier. Han agiterede for en overførsel af Voortrekkerbevægelsens ungdomsarbejde på den nationale fysiske kultur, herunder voortrekkernes »kraftfulde og behændige « lege, folkedanse, operetter og sange. Også gymnastik skulle indgå som »et nødvendigt onde«, pga. skolelivets negative indflydelse på børnenes fysiske tilstand. Artiklen var inspireret af nazistisk racetænkning, voortrekkerideologi og opbakning til, at legemskulturen i Sydafrika skulle tjene militære mål. I de følgende numre var der blandt kendte internationale bidragydere udover den tidligere danske undervisningsinspektør K.A. Knudsen og Niels Bukh kun den tyske organisator af OL i 1936, Carl Diem som kom til orde med et budskab om idrættens betydning for staten, nationen og racen. ${ }^{36}$ Diem agiterede for en styrkelse af nationen ved, at unge i tiden efter puberteten (15-19 år) blev underlagt statens direkte kontrol, hvilket han understregede allerede var tilfældet $\mathrm{i}$ de »autoritative« stater, en holdning Bukh delte, hvilket skulle vise sig efter den tyske besættelse. Bukhs artikel til det officielle program blev bragt og K.A. Knudsen portrætterede ham i to store artikler i bladet. ${ }^{37}$

Som følge af at de konservative, afrikaanerkræfter tabte kampen om Sydafrikas neutralitet gik Pirow af, hvorefter han under krigen udviklede sig i stadig mere nazistisk og tyskvenlig retning. ${ }^{38}$ Obholzer blev interneret, og hans planlagte professorat på universitetet i Stellenbosch stillet i bero. ${ }^{39}$ Det blev nu de regerende liberale kræfter, som profiterede på truppens propagandaværdi og evne til at samle den splittede hvide befolkning. Efter regeringsskiftet og beslutningen om deltagelse i anden verdenskrig var det slut med store festlige reportager om de danske gymnaster i afrikaaneravisen Die Burger. Den nye undervisnings- og finansminister Hofmeyr som nu blev dominerende på den indenrigspolitiske scene - var ansvarlig for, at turneen blev forlænget, hvilket han bekendtgjorde $\mathrm{i}$ en tale direkte til truppen i Pretoria.

Ved den første af de store opvisninger i Johannesburg var, ifølge Søgaard, næsten hele det nye ministerium tilstede. Ifølge én af gymnasterne var der fem repræsentanter for regeringen til stede med udenrigsministeren i spidsen. ${ }^{40}$ Også hærens topledelse benyttede lejligheden til i den urohærgede tid at demonstrere, at der var overskud og ro til at gå til gymnastikopvisning og at være i kontakt med befolkningen. Generalguvernør Duncan holdt en tale, hvori han sagde, at danske gymnaster var velkomne overalt, men særlig i Sydafrika på dette tidspunkt, for verden var inde i en vanskelig periode, men dette bes $\varnothing \mathrm{g}$ viste, at der også var andet at tænke på; en kult for fysisk kultur, som var skabt for både mænd og kvinder. ${ }^{41}$ Generalguvernør Duncan, som var stærkt upopulær i brede dele af afrikaanerbefolkningen, fik her en stor og tilsyneladende upolitisk platform for sin person. Det er et vidnesbyrd om turneens stærke symbolværdi, at Duncan, Hofmeyr og flere andre ministre midt i den turbulente indenrigspolitiske situation gav sig tid til at holde taler og mødes med gymnasterne, I Pretoria var truppen på besøg hos Transvaals administrator Pienaar og senere hos generalguvernør Duncan.

I det officielle program argumenterede Niels Bukh med en stærkt nazistisk inspireret retorik for, hvad han kunne bidrage med i Sydafrika. Hans gymnastiks evne til at forskønne og forbedre en nations ungdom både fysisk og psykisk og fjerne alle de »værdiløse « træk. At frigøre disse kræfter i ungdommen ville kræve en for- 


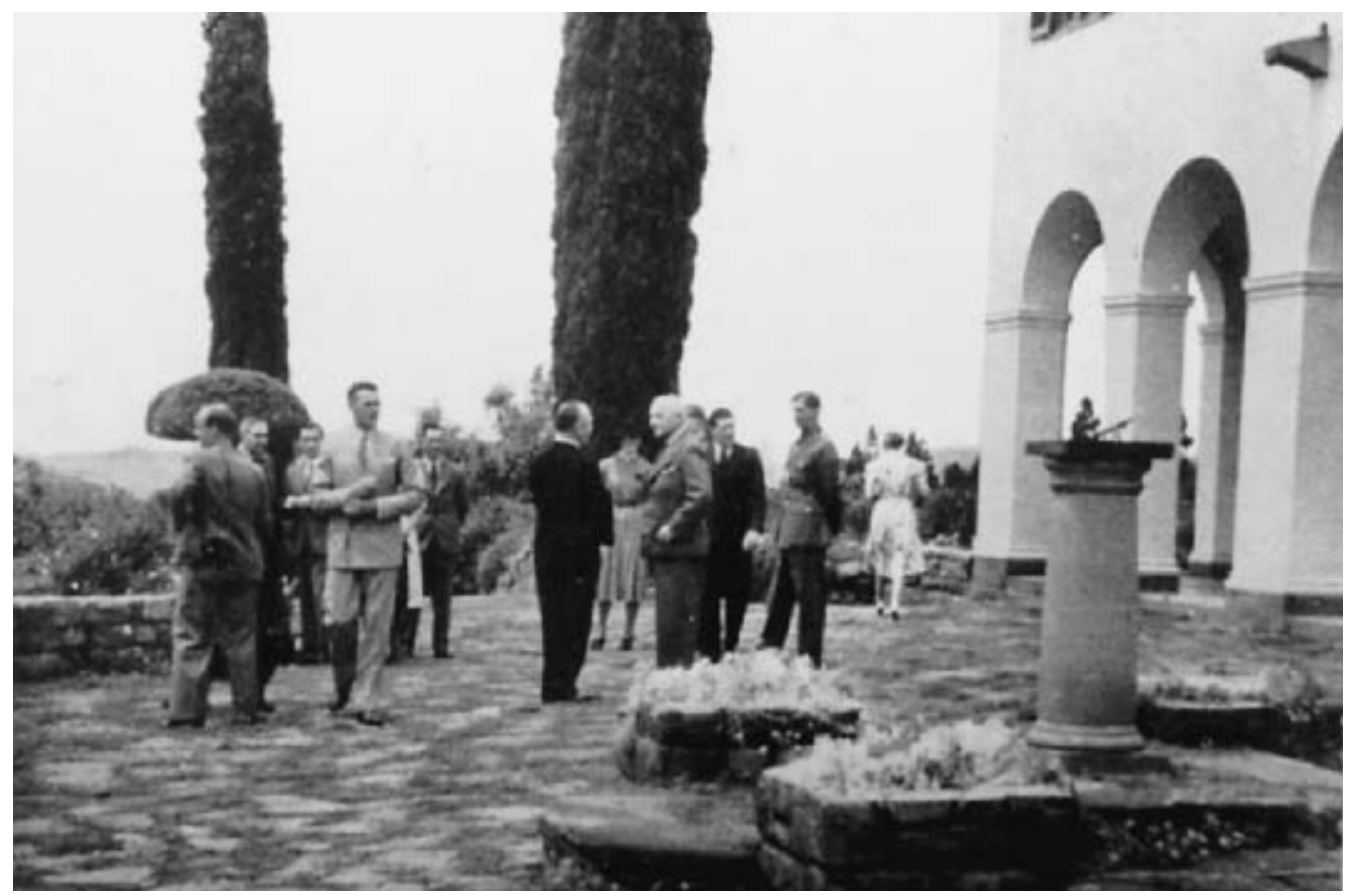

Bukh og gymnnasterne på besфg hos generalguvern $\phi r$ Sir Patrick Duncan, Kilde: S $\phi$ gaard Jorgensen, s. $128 c$.

andring fra »den forkrampede, svage og klodsede ungdomstype til en smidig, stærk og behændig person. For den første type er ikke bare utiltalende for alle at se på, men også værdiløs«, den anden var derimod smuk.

I det andet nummer af »Liggaamsopvoeding « tryktes Bukhs officielle tale til Rådet. Bukh fremhævede her sin rodfæstede idé om, at små nationer som Danmark og Sydafrika (sic! ${ }^{42}$ kun kan gøre sig fortjent til at overleve ved en blomstrende kultur og en stærk ungdom: »I Danmark anser vi ikke fysisk opdragelse for en form for fornøjelse eller underholdning, men som noget af stor national betydning... Vi danskere er omgivet af krige og er nødt til at skabe et samfund og en sund nation, som andre nationer respekterer og holder af «.

Bukh fortsatte med at sammenligne Syd- afrikas udsatte position med Danmarks, og anbefalede udarbejdelsen af et nationalt system for fysisk kultur, der skulle skabe førsteklasses unge mænd og kvinder: »ethvert samfund burde udvikle et basalt gymnastisk system, som skulle udøves religiøst af alle skolebørn og klubmedlemmer«.

Gymnastikken skulle virke opdragende, for »mine elever lærer at elske deres land og deres landsmænd. Den samme enhed og harmoni som er så vigtig for den enkeltes krop og sjæl, er essentiel for staten, hvis nationen skal blive lykkelig, elsket og respekteret«. Individets indvævning i nationen viste sig ifølge Bukh ved, at hans efterhånden 9.000 elever $\gg$ tager tilbage til deres arbejdsplads og med det samme starter en gymnastikklub i lokalområdet, hvor de underviser uden aflønning $«$. 


\section{Afrikaanere som »volk«}

Gennem Sydafrika med Niels Bukh' var titlen på en bog forfattet af Niels Bukhs lærer Agnar Søgaard Jørgensen, som var med på turen som pressekorrespondent. Forordet var skrevet af Niels Bukh, og Søgaard fortalte i bogen, og i sine artikler til danske aviser, om Niels Bukhs og gymnasternes færd og Sydafrikas historie ud fra de steder, monumenter og mennesker, de mødte på deres rejse. Gymnasternes og Niels Bukhs perspektiv fremgår klart af de artikler de skrev i danske aviser og den film, som Arne Mortensen optog. ${ }^{43}$ Dennes bror tog næsten hver aften de efterfølgende 3 vintre på turné i de danske landbokommuner med film og foredrag. Da bogen, filmen og artiklerne grundlæggende udtrykker det samme verdensbillede, og i offentligheden må være blevet opfattet som et samlet udtryk, vil de her blive behandlet under ét som »truppens opfattelse af Sydafrika«. Samtidig er de i høj grad en kilde til Niels Bukhs opfattelser, da han gennem sin tætte kontakt til arrangørerne, og som truppens meget toneangivende leder, har præget fortolkningen af, hvad der foregik. Endelig er udsagn fra alle truppens medlemmer i den danske offentlighed været med til at danne offentlighedens billede af Niels Bukh. Det kan dog ikke udelukkes, at enkelte af truppens medlemmer indimellem har haft afvigende holdninger.

Søgaards interesse for Sydafrika var blevet vakt gennem Johannes Botha, en ung afrikaaner, som var elev på Gymnastikhøjskolen i vinteren 1938-39. Hvad Søgaard ikke vidste var, at Johannes var søn af Undervisningminister M.C.Botha, ${ }^{44}$ og udsendt af Undervisningsministeriet i 3 1/2 år for at undersøge forskellige gymnastiksystemers værdi for den fremtidige sydafrikanske idrætsundervisning. ${ }^{45}$ Johannes
Botha tilhørte som sin far den relativt liberale fløj i sydafrikansk politik. ${ }^{46}$ Søgaard skrev, at han om aftnerne og på lange spadsereture udvekslede tanker med Johannes Botha om »vort land og folk«. Ifølge Søgaard var Johannes Botha som »allerede navnet antyder, en typisk boer, et stort, kraftigt friluftsmandfolk, der fra barnsben af håndterede sin riffel og red sin hest med samme naturlighed og sikkerhed, som vi danskere bevæger os på cykel, men samtidig havde Johannes Botha en brændende kærlighed til sit fædreland og dets fremtid, og denne glød, der gennemvarmede alt, hvad han fortalte, vakte min interesse for Sydafrika

Søgaard påpegede, at inspirationen til bogen stammede fra Johannes Bothas nationale engagement og herunder fokuseringen på Sydafrikas historie. Derfor satte Søgaard sig for på baggrund af litteraturstudier at skrive en rejsebog, som var historisk og kulturelt anlagt. Bogen blev stærkt farvet af Søgaards observation af, at kampen mellem englændere og boere »er i gang den dag i dag. Det er ikke mere en krig med kanoner og rifler, men en langt dyberegående kamp - en kamp om menneskets sind og følelser, en kamp mellem engelsk og boersk kultur. Søgaard spejlede flere gange boernes kamp i sønderjydernes. Kulturkampen prægede »i højeste grad boernes tænke- og følemåde, ligesom vi i Danmark kender det fra vores sønderjyder «.

Initiativet til turneen kom fra afrikaanere, især undervisningsdirektør i Oranje provinsen Pellissier, ${ }^{47}$ en mand af den konservative støbning. Han havde besøgt Gymnastikhøjskolen i 1934, og havde medvirket til at vække myndighedernes interesse for Bukhs gymnastik. ${ }^{48}$ Pellissier fortalte senere, at han havde fors $\varnothing$ gt at indføre den danske højskole i Sydafrika. På grund af de 
unge sydafrikanske landbrugeres travlhed hele året rundt, kunne der kun afholdes feriekurser, hvoraf han havde afholdt mere end 30 kurser fra 1936 til 1966. Videre fremhævede han, at »der er også et rigt folkeligt liv i den hvide befolkning. Han hævdede også at have »omplantet folkedans $\mathrm{i}$ nationaldragter fra Skandinavien til mit eget land «. Ved de store folkedanserstævner havde afrikaanerne kunnet samle op til 6000 deltagere $\ll{ }^{49}$ Pellisier rejste sammen med Bukh og gymnasterne på store dele af turen. Sammen med en anden afrikaaner, rejselederen Petterson, fik han herigennem mulighed for at forme truppens billede af Sydafrika

Undervejs på turen foregik der en gensidig identifikation mellem danskere og afrikaanerne, hvilket især tog udgangspunkt i den fælles dyrkelse af landbokulturen. Af de 16 mandlige gymnaster var 13 karle, 2 smede og én tømrer. Blandt de 15 kvinder var 4 kontorister, 5 husassistenter, 2 gymnastikledere og resten fordelt på andre erhverv. I de sydafrikanske aviser blev der ofte gjort opmærksom på, at danskerne var landbrugere og deres gymnastik skabt for landboungdommen. Hvor de engelsksprogede aviser især hæftede sig ved, hvordan opvisningerne oplevedes, koncentrerede afrikaanernes hovedavis Die Burger sig om de ideologiske overvejelser bag invitationen for at skabe en smuk og sund, hvid sydafrikansk ungdom. Pressen fokuserede i $\emptyset$ vrigt på, at Bukhs gymnastik var »volksgimnastiek « for den almindelige befolkning ikke for en sportselite.

I bogen om turneen fremhævedes det korrekt, at boer betød »de, der er fastboende på jorden, ligesom det danske ord: bonde «. Endvidere at »alle landmænd kaldes boere « uanset deres oprindelige hjemland. I en artikel publiceret både i det officielle program og i »Liggaamsopvoeding « var overskriften på Niels Bukhs artikel »den danske gymnastik for landboere«, hvilket på afrikaans blev »DEENSE BOERE-GIMNASTIEK «.

Ved landgangen i Cape Town blev holdet modtaget af en komité, der var stærkt militært- og afrikaans præget; blandt andet var Broeksma, Cape provinsens kommandant løjtnant C.J. Venter, og den danske konsul i Cape Town mødt op for at overrække Niels Bukh en velskomstskrivelse fra premierminister Hertzog. ${ }^{50}$

Bukhs hold bevægede sig nu gennem en afrikaanerkultur, der var i oprør over krigserklæringen. Truppens første opvisning foregik i Stellenbosch, som Søgaard præcist kaldte »fundamentet og det åndelige kulturcentrum for boerne «. Universitetet i Stellenbosch var på én gang førende i afrikaanernes akademiske kultur, helt central i udviklingen af den uhyre populære afrikaanerrugby og i 1936 det første universitet, som oprettede et institut for legemsøvelser. Ifølge Søgaard demonstrerede studenterne i dagene for truppens turné »kraftigt mod den afgivne krigserklæring «.

I afrikaanerbyen Paarl havde danskerne »et godt navn... fordi hele deres 'kooperative Wijnbouwers Vereiniging'... har sit forbillede i den danske andelsbevægelse «. Han hævdede, at flere »fremtrædende personligheder « udtrykte taknemmelighed til Danmark, og at borgmesteren selv havde været i Danmark for at studere andelsbevægelsen. Søgaard understregede, at det gennem andelsbevægelsen var lykkedes Paarl uden statsst $\varnothing t t e$ at opbygge et af de bedst konsoliderede eksportfirmaer i det britiske imperium og at udvikle helt nye drikke. $^{51}$

Søgaards videre rejsebeskrivelse byggede på en indlevelse i boernes koloniale historie: »Vi forlader nu Cape Town for sammen med boerne at drage ind og tage det 


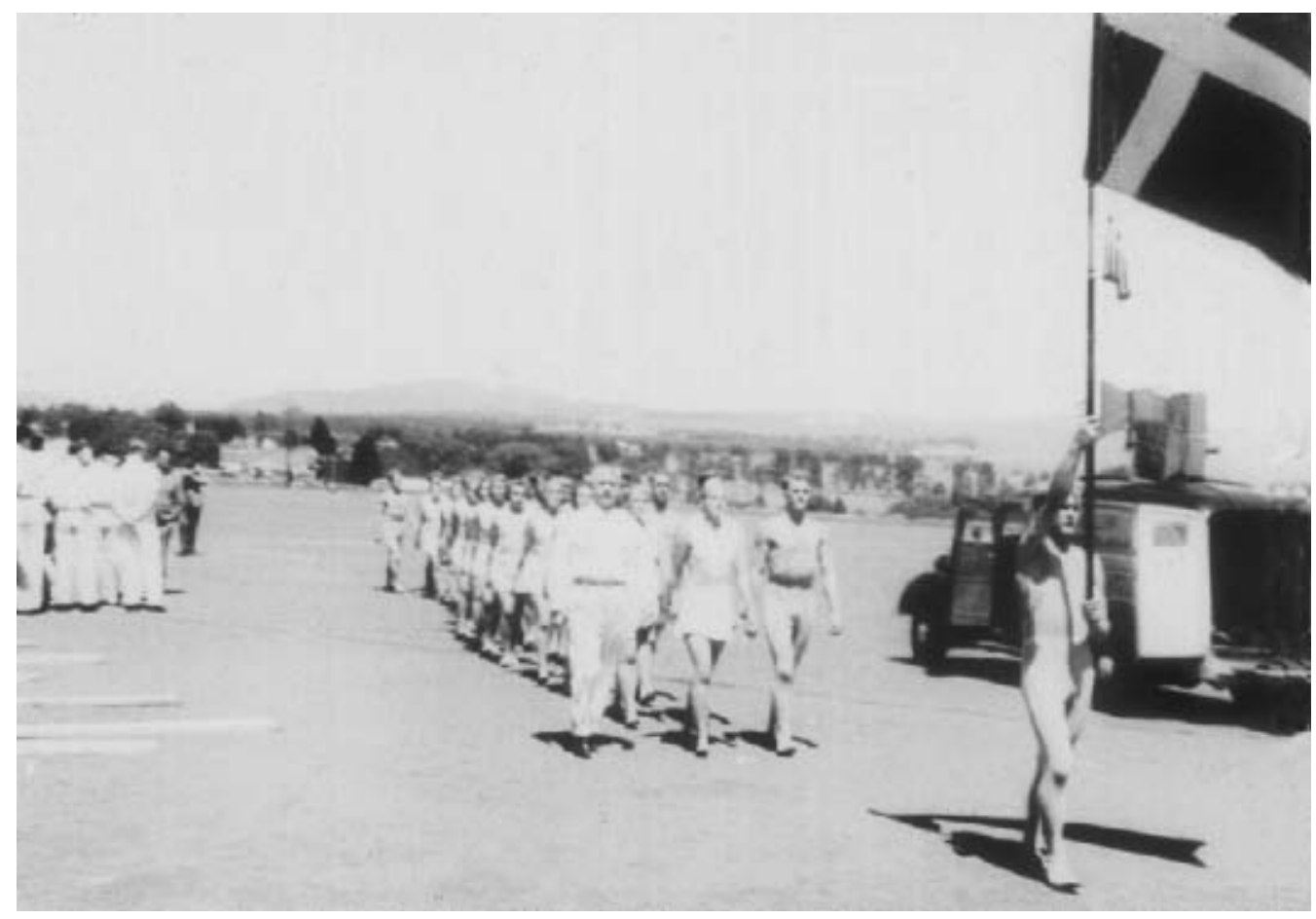

Indmarch med Bukh foran sine gymnaster, privateje.

uhyre land i besiddelse «. På denne del af rejsen blev det genkommende tema om afrikaanernes dybe kristentro første gang berørt. I Worcester som i de andre afrikaanerbyer imponerede de hvidkalkede og rene gårde: »Forøvrigt bor alle landmænd i Sydafrika i de nobleste og fineste hjem, og man mærker på renligheden, at de har gammelt hollandsk blod i årene«. Som i sondringen mellem sovjetborgere og japanere på Jordomrejsen var renhed også her et kriterium for en hierarkisering af befolkningsgrupper. Søgaard hæftede sig også ved hollændernes og danskernes fælles dyrkelse af renligheden: »Der findes vist intet folk i verden, der ligner danskerne mere end hollænderne. De har den samme renlighed og hygiejne, den samme dygtighed $i$ at lave velsmagende mad og nyde bordets glæder, den samme usnobbethed og ligefremhed i deres daglige væren, og den samme sløvhed og selvglæde«

Dernæst gav truppen opvisning i byen George, som Søgaard angav hovedsagelig beboedes af pensionerede britiske embedsmænd. Her boede de ikke hos private familier, modsat i Oudtshoorn og flere andre afrikaanerbyer. I nærheden af Oudtshoorn besøgte truppen 'Bothas hal' opkaldt efter Louis Botha, boernes general under boerkrigen og Sydafrikas første præsident. I bogen hyldedes han med inskriptionen fra Rytterstatuen i Cape Town: Landmand (boer), kriger, statsmand.

I Queenstown kørte de lokale landmænd Bukh og gymnasterne rundt til deres landbrug. Til gymnasternes overraskelse viste både mælkejunger, maskiner og metoder sig at være danske, og Søgaard fremmanede ligefrem en trussel om, at Sydafrika blev 
en farlig konkurrent for den danske landbrugseksport. Søgaard noterede sig, at man her om vinteren benytter stalde, »der er lige så fine, rene og nykalkede som i Danmark «. Én af gymnasterne anførte dog, at »efter karlenes udsagn « tålte et mejeri de beså »ikke sammenligning med et dansk «. ${ }^{2}$

I Oranje Fristaten berettede Søgaard om, hvordan de »frihedselskende, flygtende boere « i 1880 havde rejst sig til kamp mod de koloniale englændere og fra 1899 havde startet »deres store heltemodige boerkrig for fristaternes uafhængighed «. Søgaard anførte, at i hele Unionen mærker man kulturkampen mellem englændere og boere, men ingen steder mærkede man »bestræbelserne for boerkulturen så kraftigt som i den gamle boerfristat Oranje Fristaten. Her træffer man mennesker, som ikke alene ved, at de er boere, men som føler sig stolte af at være det, og som bygger videre på den gamle kultur og de gamle traditioner«.

I Springfontein mødtes danskerne »med denne lille farmerbys beboere og med landmændene fra gårdene $i$ omegnen til festligt samvær i den stedlige rådhussal, der nærmest svarer til vores hjemlige forsamlingshuse - altså de pæneste af dem «. Da afrikaanerne begyndte at danse »volksspele «, gamle boerdanse, og synge »boeremsiek «, boerfolkeviser, følte danskerne et stærkt slægtskab. Søgaard mærkede gennem »den livsglæde og naturlighed, hvormed de går op i dans og sang, at det ikke er noget kunstigt og stivnet for dem«. Initiativet til disse kulturmøder har uden tvivl været taget af undervisningsdirektør Pellissier, som var meget aktiv i revitaliseringen af afrikaanerfolkedanse i Oranje provinsen.

I Bloemfontein blev danskerne modtaget af afrikaanerne »om muligt endnu hjerteligere og venligere end $\mathrm{i}$ nogen anden by«, og igen boede de privat. Truppen besigtigede obelisken rejst over »de 26.370 boerkvinder og børn, der døde af sult og sygdom i de britiske koncentrationslejre«. »Et monument, der optænder enhver boer med glødende harme mod englænderne, og et monument, som ingen rettænkende englænder kan besøge, uden at han må føle skamrødmen blusse i sine kinder «. S $\varnothing$ gaard noterede sig, at »der i vore dage finder mange boerdemonstrationer sted « ved monumentet, og Bloemfontein var i 1939 ganske rigtigt central i afrikaanerbevægelsen, idet der her blev afholdt flere stiftende møder for nye afrikaanerorganisationer.

Truppen besøgte i Bloemfontein Glen landbrugsskole og herunder et mejeri »der er anlagt efter dansk mønster «. I filmen hed det, »Oranje Fristaten er mejeribrugets centrum i Sydafrika, og mejerimaskinerne danske «. Søgaard skrev, at staten fors $\varnothing g t e$, »at opmuntre til oprettelsen af andelsmejerier «. Han spurgte lederen af skolen, om han kunne opfordre danske landmænd til at udvandre til Sydafrika og fik det svar, at der kun var brug for »dygtige, selvstændige og fremsynede mænd... landarbejdere har vi nok af selv«.

I Pietermaritzburg besøgte truppen Voortrekkermuseet med de første vogne, som boerne anvendte, da de i Det store trek fra 1834-40 trængte fra Kaplandet dybere ind i det sydlige Afrika. I Ladysmith så de boerkrigens slagmarker. Søgaard begrundede boernes kampgejst i 1899 med følelsen af at »kæmpe for retten og for bevarelsen af deres lands selvstændighed «. Herefter rejste gruppen ind i Transvaal, hvor de gav opvisning i den lille by Standerton. Om aftenen kørte de lokale afrikaanere danskerne ud til deres farme, og næste dag besøgte de et stutteri for væddeløbsheste, en stor kvægfarm, og et mejeri. I pagt med det traditionelle agrare verdensbillede fremhævede Søgaard »den idyl og hygge, der kan hvile over en driftig by, der er fritaget for store 
industrivirksomheder og fabrikker, og dermed fritaget for den moderne storbys værste uhumskhed, slumkvartererne«. De større sydafrikanske byer $\varnothing v e d e$ slet ikke den samme tiltrækning, og Søgaard beskrev forpustet Johannesburgs »travle pulsslag«. Denne fornemmelse forstærkedes ved, at truppen $\mathrm{i}$ en periode næsten hver eneste dag skulle give opvisning i selve byen eller i nærliggende byer, som var placeret omkring guldminer og kraftstationer.

Rejsen gik dog mod roligere mål til »de to yndige boerbyer« Potchefstroom og Heidelberg samt til Vereeniging, hvor overenskomsten mellem de to boerstater »om at stå sammen i værn om deres frihed og selvstændighed mod englænderne« blev underskrevet. På vej ind i Pretoria - »en rigtig boerby « - så danskerne forarbejderne til det kolossale voortrekkermonument, som ved færdiggørelsen i 1949 blev en national helligdom i afrikaanerkulturen. Det var en fejring af voortrekkernes sejr over zuluhøvdingen Dingane i 1838. Den 9/9 et par uger før gymnasternes besøg - havde Broederbond holdt en demonstration for Sydafrikas frigørelse fra Storbritannien og for en alliance mellem broderskabet og Hertzogs fløj i en samlet republikansk front.

I Pretoria besøgte truppen militærets hovedkvarter samt den nationale politiskole, hvor én af de mandlige gymnaster senere blev ansat som gymnastiklærer. I Sydafrikas nordligste by Pietersburg besøgte de en ungdomsskole for afrikaanere. Udenfor Kimberley beså de fire mindesten, som var rejst for de 49 »skandinaviske helte «, der kæmpede for boerne og dræbtes ved Magesfontein. Søgaard nævnte, at »disse menneskers indsats har betydet uendelig meget for os skandinaver i Sydafrika. Enhver afrikaaner fyldes med beundring, når han hører, at man er skandinav «.
Minedistrikterne omkring Kimberley gav Søgaard anledning til den eneste direkte positive bedømmelse af englændernes indsats i Sydafrika; Cecil Rhodes' kamp for valgrettigheder til de engelsktalende hvide $\mathrm{i}$ Transvaal og arbejdet for et Commonwealth af uafhængige stater under den britiske krone.

Også langt senere fastholdt Niels Bukh sit særlige forhold til afrikaanerne i vendinger, han ellers normalt ikke brugte. I et brev til en hollandsk gymnastikinspektør skrev han i 1945: »Da krigen kom opholdt jeg mig med to gymnastikhold i Sydafrika hos deres udmærkede landsmænd 'boerne', som blev mine hjertensvenner «. ${ }^{53}$ Det skal dog understreges, at Bukh på dette tidspunkt af politiske grunde havde brug for så mange positive udenlandske kontakter som muligt.

\section{Sort/hvide billeder}

»Indenfor svineavl er landbrugsskolerne begyndt at eksperimentere med de hvide svineracer, og de synes at være kommet til et meget lovende resultat $\ll$.

I sin bog gav Søgaard en meget kras racistisk skildring af de ikke-europæiske befolkningsgrupper, som ikke kunne undgå at blive tillagt Niels Bukh i den danske offentlighed. Anvendtes udtrykket »sydafrikaner « mentes der altid en hvid. Helt i tråd med den hvide raceideologi optrådte de ikke-europæiske befolkningsgrupper kun, hvis de eksplicit nævntes. De sorte sydafrikanere fremstilledes som på én gang fascinerende og skræmmende, som ædle, men også uciviliserede vilde. Turistens blik viste sig især i filmen, hvor det om sorte mænd, der rejste til og fra arbejde, hed, at de var i alle mulige »kostumer«.

Det var en uudtalt forudsætning, at den 
danske gymnastik skulle indgå i den hvide kultur. Blev farvede undervist heri, var det ét blandt mange adgangstegn til den hvide verden. Ikke desto mindre var det sorte sydafrikanske børn, som viste Bukh og gymnasterne den fineste gymnastik. På en praktisk orienteret skole for sorte børn i Ladysmith demonstrerede børnene et »uhyre levende og rytmisk fint afbalanceret« selvlavet gymnastiksystem«, og »de små negerbørn gik op i det med en interesse og iver, som vi ikke fandt noget tilsvarende til noget andet sted i Sydafrika ${ }^{54}$

Fik farvede lov til at overvære en opvisning for hvide, var deres plads bag ved holdet med solen i øjnene, medens de gode pladser foran holdet og på de skyggefulde tribuner, var »kun for europæere«. Denne erkendelse indfandt sig dog først senere på turen, for tidligt på rejsen, fortalte Søgaard i en dansk avis, at ca. 86.000 tilskuere $\gg$ af alle kulører og repræsenterende alle alderstrin, har overværet opvisningerne $\ll{ }^{55}$ Truppen hilste normalt over mod tribunerne, hvor de hvide sad. ${ }^{56}$ Da opvisningen i Cape Town på grund af regn blev flyttet indendørs, fik kun de hvide lov til at benytte deres billetter. Om opvisningen i Paarl skrev en kvindelig gymnast indigneret, at den billige langside var optaget af de sorte: »altid skal de farvede være isolerede og på det dårligste sted $\ll .{ }^{57}$ Søgaard erkendte privat, at sorte sydafrikanere stod og kiggede gennem stadionernes hegn og grinede af de hvide gymnaster, som svedte under den stærke sol $»$ til ingen verdens nytte $\ll{ }^{58}$

I 1938 og 39 var afrikaaner nationalisterne særligt aktive for at udbygge raceadskillelsen..$^{59} \mathrm{På}$ et tidspunkt, hvor apartheidsystemet langt fra endnu var officielt indstiftet, kunne Søgaard berette til den danske offentlighed om udviklingen i raceadskillelsessystemet, idet lovgivningen »forbyder giftermål mellem de forskellige ra- cer, og man er begyndt at rive slumkvartererne ned og bygge nye, store kvarterer, hvor hver race holdes strengt adskilt«. Han registrerede »en skarp skillelinje mellem europæerne og de farvede folkeslag. Toiletter er »kun for europæere«, bænke i parken er påmalede »kun for europæere«, første og anden klasse i toget er »kun for europæere, osv «. Om raceadskillelsen konkluderede han, at det var vanskeligt for »en såkaldt 'human europæer' at sætte sig ind i de følelser, som ligger bagved, og endnu vanskeligere er det at bedømme eller fordømme forholdene «.

Søgaard observerede, at »alt arbejde på gårdene i Sydafrika udføres af kulørte og negre. Den hvide farmers indsats består mest i det forretningsmæssige og $i$ at overvåge, at arbejdet bliver gjort. Man kan nemlig ikke stole på de farvede, og man risikerer hvert øjeblik, at de uden videre forlader arbejdet og rejser deres vej. De er uhyre billige sammenlignet med europæisk arbejdskraft, men de kender heller ikke spor til at skynde sig med et arbejde, og forstår langt mindre at gøre et selvstændigt arbejde«. Søgaard var meget negativ overfor de farvede, eller som han kaldte dem »kulørte«, som han allerede i Cape Town stødte på i stort tal: »De kulørte i Kapprovinsen er et folk, der står midt imellem europæerne og negrene, og de er, med deres europæiske opdragelse og civilisation, men deres manglende selvstændighed og energi, et problem for hele samfundsspørgsmålet i Sydafrika. I byerne bor de ude i slumkvartererne, og fra deres rækker fostres de fleste forbrydere og voldsmænd i Sydafrika«. I afsnittet om Durban behandlede Søgaard det store indiske indslag i Sydafrika og harmedes over, at inderne nærmest blev holdt nede »på samme niveau som negrene«. Indernes skønhed blev stærkt fremhævet i modsætning til de sorte sydafrikaneres. 
I forbindelse med opholdet i Cape Town berettede Søgaard om det koloniale Sydafrikas tidligste historie. Han fortalte, at de hollandske pionersoldater søgte at komme »i fredelig kontakt med de små buskmænd (d.v.s. skovmænd), der levede deres uhyre primitive jægerliv oppe i bjergene«. Men det viste sig hurtigt umuligt, at »fæste nogen som helst tillid til disse vandrefolk, som den ene dag kunne handle fredeligt og den næste dag skyde den hvide mand ned bagfra med deres forgiftede pile«. Efterhånden blev de opfattet som »farligere end vilde dyr, og det blev tilladt at skyde dem ned, når man så dem. Buskmændene kunne »ikke indordne sig under europæerne eller leve sammen med andre stammer, og resultatet er, at de i dag er så godt som udryddet«. Det kan tilføjes, at det anslås, at mange tusinde buskmænd blev udryddet ved, at boerkommandoer helt frem til 1882 jagtede dem som en form for sport. ${ }^{60}$

Søgaard skrev, at buskmændene trivedes godt som slaver i boernes landbrug, men da de på grund af britisk missionsvirksomhed og humanisme blev frigivet, kom de for alvor i berøring med civilisationen og gik til grunde. Han kritiserede også forestillingen om, at de hvide havde taget landet fra de sorte. Der var snarere tale om, at de udefrakommende »kaffere « var draget hærgende frem fra syd, idet de udryddede den oprindelige befolkning. På et tidspunkt stødte de på de hvide, som altså ikke var mere fremmede end »kafferne«.

I Worcester så truppen nogle nye arbejderboliger, som en vinbonde havde bygget, hvilket han påstod var »et stort fremskridt med hensyn til lys og arbejdsforhold «. Der var kun ét rum til en hel familie, og det var af en sådan art »at en dansk landmand ikke engang ville byde sine grise det«. Gulvet var af cement og der var kun ét lille vindue, som sad i loftet. På Søgaards spørgs- mål, om ikke »de farvede « var utilfredse, svarede gårdejeren, »nej tværtimod... vi har fors $ø$ gt at lægge bræddegulve og sætte almindelige vinduer i, men den første dag efter indflytningen drak de sig som altid fulde, slog ruderne ud og brækkede gulvet op og brugte det som ildebrændsel «. På spørgsmålet om det passede, at der var landmænd, der mishandlede deres arbejdere, svarede gårdmanden, at det kunne forekomme, men det var sjældent. »Vi er alt for afhængige af dem som vores arbejdskraft, og vil kun gøre alt muligt godt for dem, men man må huske, at de sorte kun respekterer den «.

Opfattelsen af de indfødte som tilhørende naturen modsat de hvide kulturmennesker var en fast europæisk forestilling i mellemkrigstiden. Stammen blev opfattet som en »naturlig enhed « i modsætning til europæernes civiliserede liv i familier og byer. ${ }^{61}$ Ved Amaxosa besøgte truppen en landsby. Én af gymnasterne berettede, at kafferne var »fuldstændig uciviliserede. De hylede og skreg og var bange for fotografiapparater. Gamle mænd og kvinder så hæslige ud. Efter vore iagttagelser her, er det tvivlsomt om Europa bør søge tilbage til naturen. Jeg tror ikke nogen af vor turné melder sig som disciple i en sådan forening ${ }^{62}{ }^{62}$

I filmen hed det mere positivt: »Ud til de indfødtes eget land, hvor ingen hvid mand har noget at gøre«. »Her lever kvinder og børn deres frie, naturlige liv i kubeformede hytter, mens manden arbejder i minerne eller på fabrikker «. Søgaard var betaget af de nøgne børn »med struttende topmaver og smilende med deres kridhvide elfenbenstænder. Buttede, sunde og trivelige i al deres chokoladebrunhed. Om mændene hed det i filmen, at de »regerer og forsvarer familien og stammen « og "går til krigsdans $i$ kraalen«. Søgaard anførte, at de indfødtes 


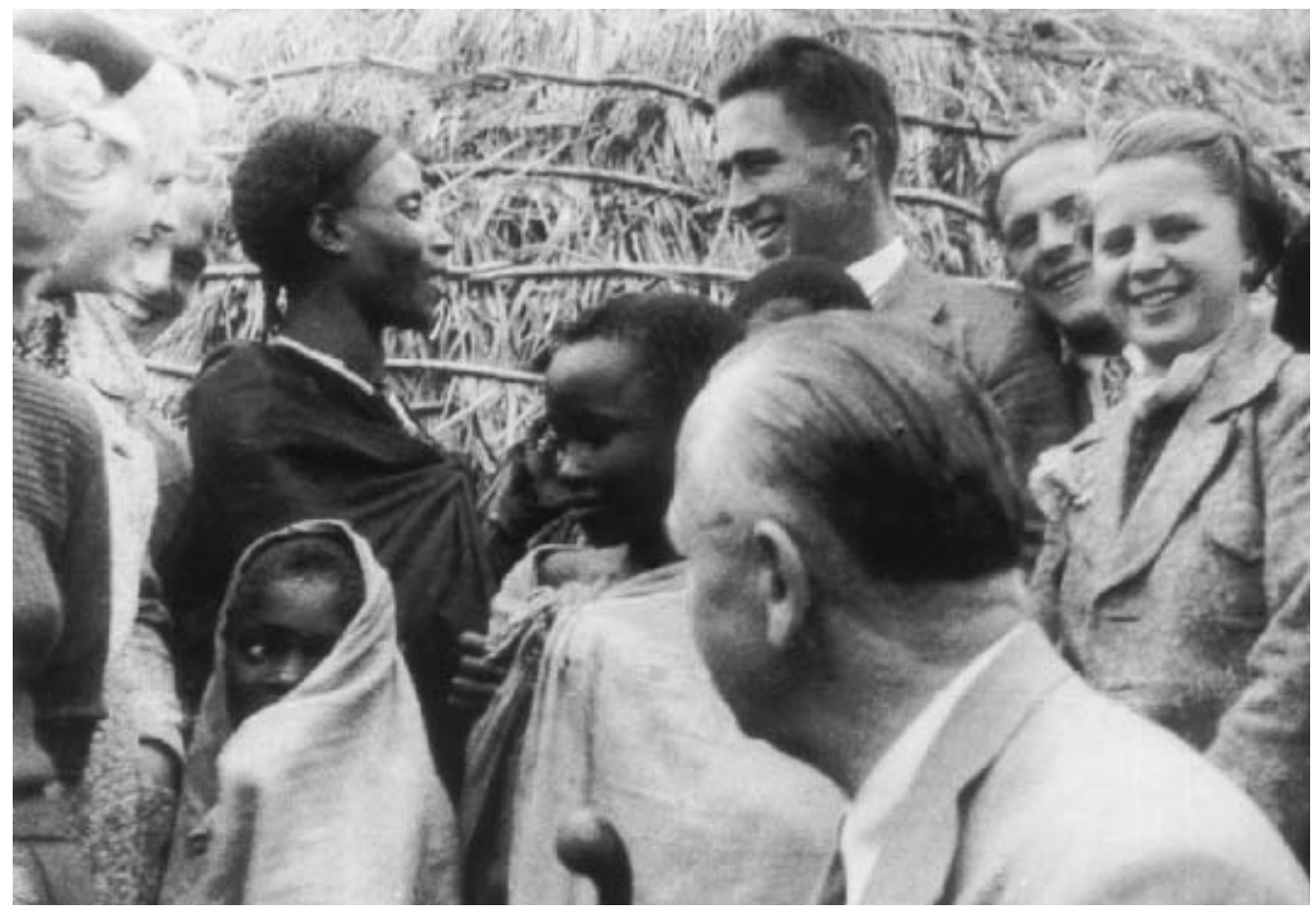

Sort og hvidt mфdes. Bukh har vist et godt фje til et lille afrikansk barn. Kilde: Søgaard Jørgensen, s.96c.

$»$ kraaler« indføjede sig »naturligt og skønt« i landskabet i modsætning til de skæmmende europæiske barakker og huse.

Hvor de sorte sydafrikanere kunne opfattes sympatisk i deres »kraaler og $»$ stammer«, gjaldt det samme ikke for de mange, som var indvandret til byerne. Søgaard skrev, at europæiske klæder passede dårligt til de indfødte. Som regel var det nogle »jammerlige laser, de optræder i «, men selv når de kunne siges at være nogenlunde velklædte, var der »noget tragikomisk, unaturligt over deres optræden og bevægelser i civilisationens klædebon«. Lige så »naturligt, skønt og harmonisk zulunegeren glider ind i den sydafrikanske natur, lige så kluntet og kejtet virker han i byerne, hvadenten man så ser ham vaske trapper, køre bil eller feje gade«. Talrige zuluer blev »opslugt af bylivet og vender aldrig mere tilbage til kraalerne... men de angribes til gengæld også af civilisationens skyggesider... deres helbred svigter... Deres moralske niveau hæves som regel heller ikke ved efterligning af europæerne, og de lærer at benytte de moderne kampmidler i arbejdsstridigheder: Strejke og boycot «.

I nærheden af Qeenstown besøgte truppen påny en »negerlandsby«. En gymnast skrev, at »selv om der var en utrolig mængde nøgne, sorte børn, var der en vidunderlig fred og ro over hele det primitive liv, disse negere levede. En anden gymnast fremhævede, at:

»Ved besøg hos negere er der en ting, der altid støder de hvide, det er den specielle negerlugt. Man får uvilkårlig trækninger i 


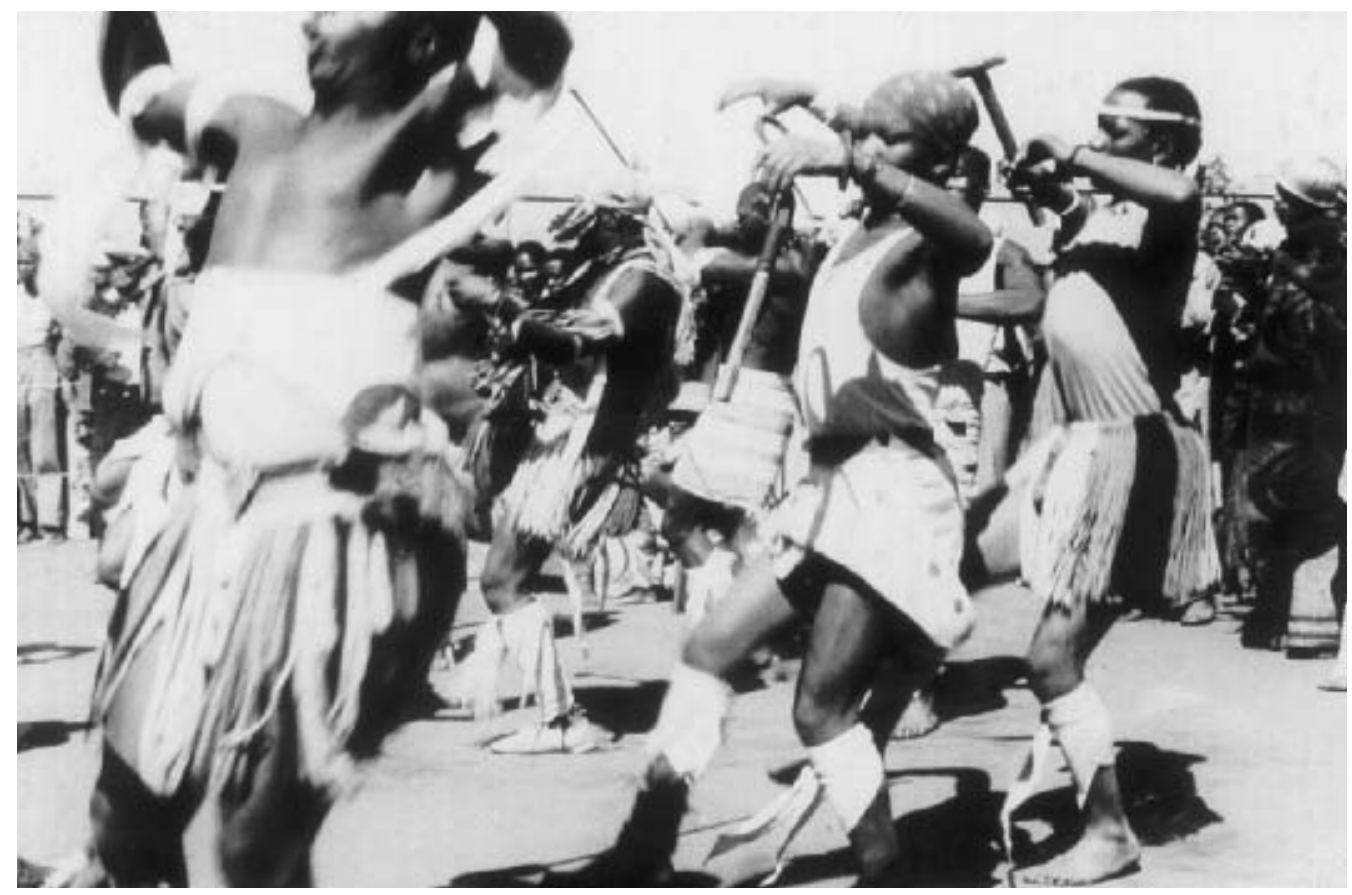

Der var en sterk fascination af de sortes dans, privateje.

næsehuden. Lugten af negere og disses boliger er ubestemmelig, men afgjort ubehagelig $« .{ }^{63}$ I Durban bes $ø$ gte truppen et »indfødt marked«, men »huha, sikken en stank «. Udenfor Durban besøgte de igen en $»$ negerlandsby«. Gymnasten skrev, at »der var nogenlunde rent, men maden, de lavede så mindre appetitlig ud«. Hun var dog tiltrukket af de sorte afrikaneres mange farvestrålende smykker og de ældre kvinders lerindsmurte hår. ${ }^{64}$

I beskrivelsen af rejsen gennem Transvaal var Søgaard især optaget af historien om boernes kolonisering. »Hvor de drog frem, stødte de på krigeriske negerstammer, og hvor de bosatte sig, var det i en stadig kamp med de indfødte og frygt for deres natlige angreb «. Boernes kampe mod zuluerne i Natal blev beskrevet ud fra synsvinklen de blodtørstige, grufulde zuluer, som dræbte forsvarsløse hvide kvinder og børn, og han hyldede derfor afrikaaner- nes største nationale festdag »Dinganes dag « den 16 december.

Truppens mest eksotiske oplevelse var uden tvivl de sorte sydafrikaneres trancedans, som dannede en stærk kontrast til truppens egen relativt stive og disciplinerede vesterlandske kropskultur, hvilket der dog ikke reflekteredes over. Der var både tale om en fascination og en angst for, hvad den ustyrlige sorte krop kunne finde på. Skønt også Bukh var stærkt fascineret af denne kropskulur medførte det ingen reflektion hos ham i relation til hans teori om, at udvikling af kroppen samtidig medførte en udvikling af karakteren. De sortes fysiske evner blev gjort til et udtryk for deres naturtilstand: Søgaard fortalte, at som om »vanvid havde grebet alle danserne, styrter de frem, trampende og stampende, alle med samme rytme og med de samme bevægelser. De kaster overkroppen tilbage, skyder underlivet frem, medens benene går 
som små trommestikker... Som en hest der er stukket af en bremse sparker og stamper de, mere og mere ophidsede, fuldstændig selvforglemmende, kaster de skjoldene i jorden med et drøn, tramper på dem og lægger nakken tilbage, hylende op mod de drivende skyer. En enkelt af dem går fuldstændig i ekstase, glider ud af holdet og stamper og vrider sit sveddryppende legeme i konvulsiviske krampetrækninger. Gymnasterne sad i to timer og betragtede dette »mageløse udtryk for menneskelig naturudfoldelse «.

De sortes danseres mangel på kontrol kunne også vække anstød og angst. Ved et senere besøg i Witwaterstrand i nærheden af Johannesburg overværede truppen en række danse. Det var søndag, og minearbejderne fra forskellige sorte »stammer dansede for hinanden. I filmen hed det, at $»$ i minebarakkerne, hvor de kontraktbundne negere lever, giver fridagenes danse ofte politiet besværligheder « og andetsteds i filmen hed det, at: »I alle europæiske byer samles negrene hver lørdag og søndag i fuld krigsmaling og danser sig fra sans og samling «. Én af de kvindelige gymnaster fortalte om dansene, at det der gjorde stærkest indtryk, var de farvedes krigsdanse. Hun understregede, at den guldmine, de besøgte, beskæftigede 10.000 indfødte, og at de kom »lige fra negerkraalerne«. Deltagerne i dansen gik op i den med en $»$ vidunderlig, djævelsk vildskab, som nærmer sig ekstase, ledsaget af koret, der klapper, og så vidt jeg kunne høre, stadig gentog den samme sætning. Danserne selv frembragte nogle lyde... Omtrent som mennesker i åndenød, alt imens de slyngede det ene ben hårdt $\mathrm{i}$ jorden og vrikkede med deres smidige krop. Man fortalte os, at krigsdansen i reglen måttes standse, for at det hele ikke skulle udarte til slagsmål og drab«.

Bukh var dybt fascineret af de sortes fy- sik og bevægelser, som inkarnerede det "primitive « idegrundlag i hans gymnastik. I 1941/42 konkluderede han om zuluerne, der »lever helt frit«, at deres smidighed, kraft og »hele legemsskønhed « måtte være et rigtigt udtryk for, hvad der er naturligt«. Deres dans »åbenbarer langt større smidighed, kraft og behændighed, end selv den bedst gennemarbejdede primitive gymnast kan præstere $\ll{ }^{65}$ Det skal her understreges, at Bukhs opfattelse af zuluerne netop gik på deres kropslighed, en sammenkædning som var udbredt i mellemkrigstiden, og som indfortolkede de sorte fast $i$ en legemlig de hvide i en hovedsagelig åndelig dimension.

Minearbejdernes liv i kasernerne var ifølge Søgaard ikke uproblematisk. Hvis kasernens regler blev overtrådt, foregik afstraffelsen $» i$ reglen ved en omgang af en pisk «. Der var i forhold til de hvide ekstremt lave lønninger og store arbejdsmiljøproblemer med dødsfald til følge, fordi støvet fra de mange sprængninger satte sig i luftrøret. Én af de danske sydafrikanere, som havde været med til at arrangere besøget i guldminen fik gennem besøget lejlighed til at videregive en helt anden opfattelse af virksomheden til den danske offentlighed. Jaques Kaufman berettede om den sunde kost og forsikrede, at boligforholdene var »meget moderne med store højttaleranlæg til nyheder og musik og hyggelige barakker med tyve indbyggede køjesenge i hvert soverum «. ${ }^{66}$

Bukhs reaktionære forbindelse med afrikaanerne satte også sit præg efter hans død. Én af gymnasterne Anne Lise Stoltz, som var gymnastisk uddannet på Medauskolen i Berlin og tidligere lærer på Gymnastikhøjskolen, blev gift med en gymnastiklærer, som underviste i Spesiale Diensbataljon (SDB). Stoltz blev gift ind i et afrikaanermiljø, hvor hun fik den tidligere mi- 
nister »for indfødtes anliggender« (fra 1933-38) Piet Grobler som svigerfar. Grobler udviste i løbet af 1930'rne autoritære tendenser og foreslog i 1936 en afskaffelse af det parlamentariske system. ${ }^{67}$ Hun blev opfordret til at skrive i Gymnastikhøjskolens årsskrift fra 1953, hvor hun med meget kras racisme søgte at begrunde de hvides formynderskab og den netop iværksatte apartheidpolitik, idet hun i vanlig konservativ, hvid stil gjorde kampen for en opblødning af racepolitikken synonym med kommunismens fremtrængen. Inderne var altid blevet betragtet som »uvelkomne gæster af andre befolkningsdele «. Det er en »forvirret racegruppe«, som »evig og altid« er i modstrid med loven, og ofte stræber mod at forværre raceforholdene. »De fleste hvide fortænker dem derfor også $\mathrm{i}$, at blive den 5te kolonne i en fremtidig østlig imperialisme i Afrika«. Stoltz påstod, at både farvede og hvide holdt apartheidsystemet i hævd. Truslen kom udefra dels gennem »det imperialistiske, britiske program« som var under påvirkning af blødsøden humanisme i racespørgsmålet, dels »visse udenlandske missionsstationer «, og sidst, »men ikke mindst, er der de kommunistiske agitatorer, som bliver mere og mere foretagsomme her i Sydafrika, som i andre verdensdele $\ll$.

I 1966 gæstede Pellissier Gymnastikhøjskolen. I et interview i Svendborg Avis benyttede han lejligheden til at kritisere »danskernes fordømmelse af Sydafrikas racepolitik«, som var »baseret på ukendskab til de virkelige forhold og desuden stærkt påvirket af kommunistisk agitation «. De virkelige forhold var derimod, at »den farvede befolkning « ikke blev mishandlet og ingen steder i Afrika havde det så godt som i Sydafrika. Derfor forsøgte mange sorte fra nabolandene da også at komme ind i Sydafrika. ${ }^{68}$

\section{Gymnastikeksport}

I Undervisningsministeriets første rapport til regeringen efter Niels Bukhs bes $\emptyset \mathrm{g}$ blev reformeringen af undervisningen i legems$\emptyset$ velser forstået som »det vigtigste spørgsmål, som vores undervisningsautoriteter er konfronteret med«. Den basale idé i primitiv gymnastik sås som grundstenen i al moderne legemskultur, herunder den sydafrikanske. ${ }^{69}$

Opfattelsen af Niels Bukhs gymnastik som det rette system, blev udsat for kraftig kritik. I Undervisningsministeriets rapport det følgende år afvistes den »stadigt eksisterende mistanke ${ }^{70}$ at Bukh og hans gymnaster var inviteret til Sydafrika, fordi Rådet havde til hensigt at indføre dansk gymnastik holus bolus. Det den danske trups besøg havde vist var, at eksperimenternes tid nu var forbi, og en ekspertkomité på ni mand blev udnævnt. Denne komité havde som mål at lave lærebøger for elever, studerende og lærere.

Det blev den traditionelle skandinaviske model for legems $\emptyset$ velser, som blev grundlæggende i undervisningssystemet. ${ }^{71}$ Gymnastikken blev anset for grundlæggende $\mathrm{i}$ forhold til den britiske sport, ${ }^{72}$ og konkurrencer, særligt i atletikken, skulle ikke anvendes til rekorddyrkelse, individuel selvhævdelse eller for tidlig specialisering, men til glæde ved deltagelsen og fremme af holdånd i forhold til udøvernes gruppe og/eller skole. ${ }^{73}$

Niels Bukhs gymnastik fik stor betydning både i foreningsidrætten ${ }^{74}$ og i uddannelsessystemet. ${ }^{75}$ Derudover kom inspirationen fra svensk, tysk, østrigsk og anden dansk gymnastik. ${ }^{76}$ Bukh deltog $\mathrm{i}$ »en del konferencer med Rådet for tilrettelæggelsen af gymnastikundervisningen ved sydafrikanske skoler og seminarier «. Der blev lavet en »propagandafilm « af opvisnings- 


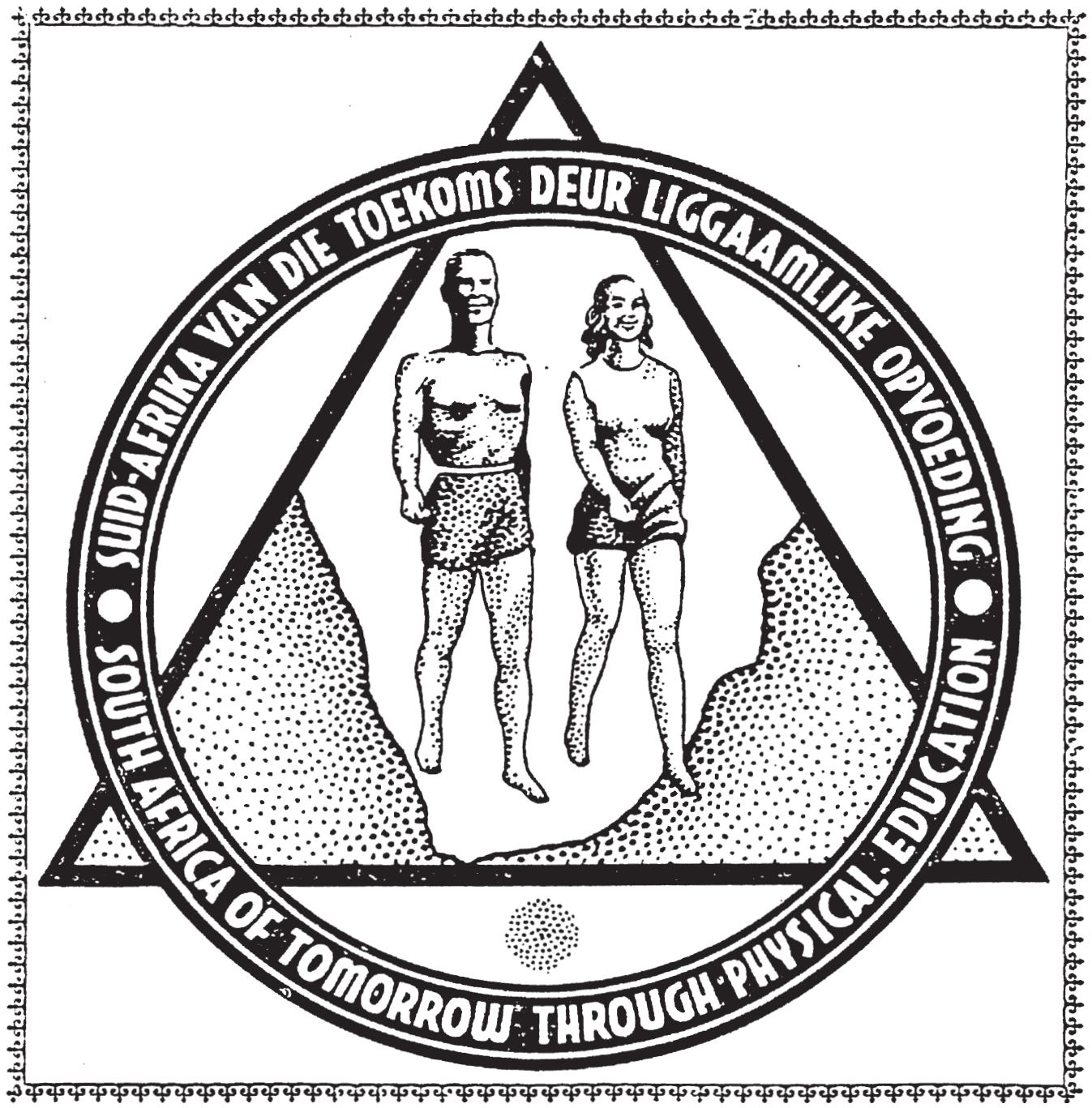

Bukhs gymnastik blev et vartegn for "Fremtidens Syafrika gennem legemskultur «, kilde: Leerplan vir liggaamlike opvoeding, senior book I, Pretoria, 1947.

programmet og optaget en instruktionsfilm til skolerne. Planer om at sende hele hold af sydafrikanske elever til Gymnastikhøjskolen blev skrinlagt sandsynligvis på grund af krigen. Kun 2 kvindelige sydafrikanske elever (i 1943) og én mandlig (i 1947/48) gennemførte kursus på Gymnastikhøjskolen inden 1950, alle var afrikaanere. ${ }^{77}$

Målet for den fysiske opdragelse for større børn og voksne blev skabelsen af en sund, stærk, udholdende og velskabt krop. Det faste symbol, som markerede et nyt Sydafrika på legemskulturens område var en tegning af to unge fremadmarcherende, veltrænede hvide, en mand og en kvinde, som fyldte et landkort af hele det sydlige Afrika. Manden var i shorts og med nøgen, muskuløs overkrop, hvilket uden tvivl var inspireret af Niels Bukhs maskuline æste- 
tik. Teksten lød: »Fremtidens Sydafrika gennem fysisk opdragelse «. Det var ikke kun kroppen, som skulle bringes på fode gennem legemsøvelser. Eleverne skulle også lære social opførsel og disciplin og udvikle karakter, ansvarsfuldhed og mod. ${ }^{78}$

Fire danske gymnaster blev i Sydafrika for at bidrage til »standardiseringen af gymnastikken «. ${ }^{79}$ Standardiseringen var dog ikke total p.gr. af provinsernes udstrakte selvstyre. ${ }^{80}$ Centrale $\varnothing$ jenvidner bekræfter, at dansk gymnastik blev udøvet i skolerne i stor målestok i 40'rne og 50'erne. ${ }^{81}$ Gymnasterne blev aflønnet direkte af uddannelsesstederne og var af regeringen garanteret betalt hjemrejse uanset tidspunkt. Gunver Kirkegaard blev ansat på det gymnastisk indflydelsesrige hovedkvarter Witwatersrand Technical College i Johannesburg indtil slutningen af 1942. Anne Lise Stoltz blev et symbol på det kvindeideal, som myndighederne hyldede. Hun var hovedmodellen i lærebogen for større piger og kvinder og viste sammen med en anden af de danske gymnaster Lisbeth Lange forskellige $\varnothing v e l s e{ }^{82}$. Hun blev også tilknyttet Rådet som ekspert. På det indledende helsidebillede i lærebogen for piger og kvinder vistes hun $i$ en tøndebåndsøvelse på én gang graciøs og stærk og med ansigt og arm søgende mod himlen

\section{Gennem det krigsramte Europa}

I den danske offentlighed blev opmærksomheden om truppen forstærket af dennes hjemrejse gennem krigszoner. ${ }^{83}$ Kort efter det oprindeligt aftalte tidspunkt for hjemrejsen bredte der sig en uvished om truppens skæbne. Udenrigsministeriet rettede en forespørgsel til de britiske myndigheder, og Nationaltidende påbegyndte en un- dersøgelse, hvori den britiske avis »The Daily Telegraph « medvirkede. Det viste sig dog hurtigt, at truppen på grund af krigsudbruddet slet ikke var kommet af sted. $^{84}$

Hjemrejsen bar klart præg af, at Bukhs sympati var på Aksemagternes side. Ifølge Bukh var grunden til den sene afrejse, at »det skulle være med en engelsk båd, og jeg turde ikke lade karlene og pigerne benytte en krigsførende nations skib. Jeg telegraferede derfor for en sikkerheds skyld hjem til udenrigsminister Munch, der i et svar rådede os til at foretage sørejsen med et neutralt skib «. Den 3. november rejste truppen med det hollandske luksuspassagerskib »Oranje« fra Cape Town. Her havde de det $»$ som små prinser og prinsesser undervejs, hver f.eks. med en lille javanesisk boy til vor betjening. Der var ca. 250 ombord af disse boys, der var så smukke at se på, og så rørende i deres enfoldighed « ${ }^{8}$. Truppens medlemmer mærkede nu klart, at de var uden for Sydafrika, for »for os der kommer fra den Sydafrikanske union, er det helt mærkeligt igen at sidde i salon og til bords sammen med kulørte mennesker, og at se den hensyntagen, som på alle måder bliver vist de små javanesere«.

Af frygt for Oranjes forlis beordrede rederiet luxuslineren til kaj i Lissabon, hvor truppen gav fire større opvisninger. Under opholdet indløb der meldinger om minesprængninger af skibe i den engelske kanal herunder den hollandske passagerbåd Simón Bolívar. Bukh besluttede derfor i stedet at tage hjem med et italiensk skib, for »igennem Frankrig kunne vi ikke komme«. Ud for Gibraltar beordrede engelske krigsskibe det italienske skib til kontrol. Efter et par dage rejste gruppen videre med et andet italiensk skib, og nåede via Barcelona til Genua. Allerede i Lissabon havde Bukh gennem den tyske ambassade fået 
tilladelse til at rejse gennem Tyskland. ${ }^{86}$ Truppen tog derfor nu over Berlin, ${ }^{87}$ hvor Bukh om fornødent ville kunne få hjælp af tyske myndigheder, herunder ikke mindst von Tschammer und Osten. Én af truppens deltagere erindrer: »Men da vi så skulle videre, så var alt mørklagt op igennem Tyskland. Det var nærmest lukket. Og der stod altså, at man skulle tale sagte, for fjenden hører med... Og der fra banegården, der kan jeg huske at vi måtte bære vores egen bagage i nattens mulm og mørke $\ll .88$

Omkring hjemkomsten var der stor interesse for truppen i den danske presse. Berlingske Tidende fik allerede kontakt med Niels Bukh på Korsør-Nyborg overfarten. Avisernes faste refræn omhandlede Niels Bukhs og gymnasternes »triumftog «, anerkendelsen af Danmark ude i verden, de høje tilskuertal, de sydafrikanske myndigheders interesse og muligheden for udbredelse af dansk gymnastik i Sydafrika. Der blev bragt mange billeder især ét af gymnasternes og Niels Bukhs indmarch i Cape Town under et stort dannebrog med Table Mountain i baggrunden. Et andet foto, som flere gange blev vist, var af Niels Bukh i samtale med generalguvernør Duncan. På intet tidspunkt behandledes raceproblematikken som andet end oplevelser af det eksotiske Sydafrika.

Efter hjemkomsten blev turneen som så ofte før promoveret som en national kulturmission. Det var det ikke mindst oplevelsen af det at være dansk i det fremmede, som truppens medlemmer fremhævede overfor pressen. Niels Bukh sagde, at: »Det varmede mit hjerte, når jeg så at de biler, vi kørte i, havde dansk flag på køleren, og Dannebrog vajede på de forskellige byers rådhuse, og at man altid hilste os med 'Kong Christian'. Når man er så langt borte, virker enhver mindelse om Danmark dobbelt stærk .
Bukh understregede gang på gang sine nationale mål, idet de mange tilskuere $» i$ hvert fald har fået lidt mere at vide om Danmark, om det danske flag, den danske ungdom og dets sange «. Han betonede, at den nationale repræsentation i høj grad foregik via de unges adfærdsmåde som værdige repræsentanter for dansk ungdom. Han roste Sydafrikaholdet for i den henseende at være det bedste hold, han nogensinde havde rejst med. ${ }^{89}$

En dansk forretningsmand i Johannesburg fortalte i den danske presse, at truppen havde været et samlingspunkt for danskere i Sydafrika. ${ }^{90}$ Han hævdede, at truppen i Johannesburg og omegn havde tiltrukket »alt hvad der kunne krybe og gå af danskere«, og skrev, at »ført af Niels Bukh og med et kæmpe dannebrog i spidsen marcherede det prægtige hold ind til tonerne af 'Kong Christian' - Det var et af de øjeblikke, man aldrig vil glemme. Hernede, tusinde af miles fra hjemstavnen, flammede imod os symbolet på det land, vi elsker... Mangt et $\varnothing$ je duggedes ved dette syn.«

Efter hjemkomsten arrangerede Berlingske Tidende den 17 december 2 opvisninger med »Sydafrikaholdet «i KB Hallen til fordel for avisens indsamling til »de fattiges jul«.

Et halv år senere, umiddelbart efter den 9. april, tonede Bukh rent flag i et interview med Völkische Beobachter, som bl.a. berettede om Bukhs tur til Sydafrika, hvor han havde oplevet afstraffelsen af $\gg$ de bosiddende tyskere og også mange boere, som åbent havde vedgået sig deres fjendskab mod England «. På hjemrejsen havde Bukh erfaret det engelske militærs brutalitet, eftersom det italienske skib han rejste med blev opbragt af et engelsk krigsskib og beordret til Gibraltar, hvorfra han først efter en »stærk protest « kunne give sig vi- 
dere med en italiensk damper over Genua og Tyskland og hjem til Danmark. ${ }^{91}$

\section{Konklusion}

Rejsen til Sydafrika blev Niels Bukhs sidste store internationale triumftog. Invitationen var et led i regeringens opprioritering af den fysiske kultur for den brede hvide ungdom. For myndighederne var målet at give den europæiske befolkningsgruppe et symbol på den rene, hvide, stærke krop, som var nødvendig, hvis »den hvide race« ikke skulle degenerere og miste sin fysiske kraft i forhold til de »laverestående « racer. Både den ultrahøjreorienterede fløj omkring forsvarsministeriet som Bukh delte holdninger med og de liberale i Undervisningsministeriet støttede turneen. Forsvarsministeriet især ud fra kravet om massedisciplinering af ungdommen og et styrket militært beredskab, og Undervisningsministeriet ud fra ønsket om et holdningsskifte hos den hvide ungdom i forholdet til fysisk kultur. Turneen blev en stor succes målt ud fra myndighedernes planlægning, pressens respons og den store publikumsopbakning i den hvide befolkning, som var de eneste, der havde fri adgang til opvisningerne. Efter turen blev dansk gymnastik udbredt i den sydafrikanske foreningskultur og ikke mindst i skolesystemet.

Det oprindelige initiativ til rejsen stammede fra afrikaanermyndigheder, og det var især i regioner, hvor denne befolkningsgruppe dominerede, at truppen indgik i kulturudveksling. Når afrikaanerne hyldede den danske gymnastik, hang det utvivlsomt sammen med, at den var udviklet for og af bønder. Betoningen af »volket «, og den fysiske styrke i afrikaanerkulturen gjorde den modtagelig overfor Bukhs krævende holdgymnastik, som kunne symbolisere afrikaanernes eller de hvides en- hed. Danskerne spejlede sig i afrikaanernes kultur, som bragte mindelser om idealerne bag dansk landbokultur i den stærke betoning af selvejet, de rene, velholdte, hvide gårde og kristendommen. Grundtvig blev genfundet $\mathrm{i}$ form af Krüger, forsamlingshuse $\mathrm{i}$ form af afrikaaner rådhuse og sønderjyderne i boernes kamp for selvstændighed. Truppen var med til at skabe et positivt billede af raceadskillelsespolitikken på et tidspunkt, hvor der i den danske offentlighed var stor uvidenhed om forløberne for apartheidsystemet. Turneens symbolværdi ændrede sig under anden verdenskrigs udbrud fra en sammenvævning med afrikaanerkulturen til momentant at indgå i samlingsbestræbelserne i et splittet hvidt Sydafrika, hvilket de liberale kræfter ikke var sene til at udnytte.

Gennem Sydafrikarejsen kunne Bukh føje en afrikaaneropfattelse af begrebet volk til den tilslutning til nazisternes »Völkischkeit «, ${ }^{92}$ som han havde udviklet efter et besøg i Berlin i 1933, hvilket må have bestyrket ham i troen på nødvendigheden af, at det enkelte folk i yderste konsekvens kunne indgå i hårde eksistenskampe med andre folkegrupper. I Danmark medførte truppens og i særdeleshed Søgaards formidling af rejsen, at en ret kras racisme mod sorte og farvede kunne lægges til Niels Bukhs i øvrigt reaktionære profil. Det skal dog erindres, at de sorte afrikanere generelt blev opfattet som tilhørende naturen og primitiviteten i den europæiske offentlighed. For Bukh og gymnasterne var de sorte dansere en udfordring. Bukh ønskede jo netop at fremkalde den »primitive« smidighed og adræthed $\mathrm{i}$ den hvide »degenererede« kultur. Den sorte dansende blev på én gang en kontrast til og en spejling for gymnasternes relativt stive og disciplinerede kropsideal. På den ene side var de sorte danseres vildskab og 
ekstase provokerende og tendentielt farlig. På den anden side var de stærke og atletiske sorte kroppe Sydafrikas bedste bud på en effektiv og alsidig kropskultur.

Niels Bukhs rejser gennem 1930'rne viste klart, at hans gymnastik nød den største bevågenhed i ideologisk betonede, højreorienterede dikaturer som Japan, Tyskland og Sydafrika, som dog rummede et parlamentarisk demokrati for det ganske lille hvide mindretal. Fascinationen af Niels Bukhs gymnastik skyldtes uden tvivl behovet for krigsforberedelse, for propagan- distisk at stille en idealkrop op for befolkningen og for at give stærke symboler på folkets enhed, hvilket et gymnastikhold, der nærmest virkede som én stor organisme, var velegnet til. Bukh sympatiserede med diktaturets idé, men dertil kom, at hans meget hårde gymnastik, som godt nok var blevet taget positivt op af den seldisciplinerende danske gårdmandsklasse, næppe kunne forventes at blive en massebevægelse andre steder, men ved diktaturets hjælp kunne gennemføres fra oven.

\section{NOTER}

1. Artiklen bygger på materiale fra en forskningsrejse til Statsarkivet i Cape Town i juli 1995 og fra arkivet på Gymnastikhøjskolen i Ollerup samt interviews med deltagere fra turen.

2. Bukhs officielle tale til Die Nationale adviserende Raad insake Liggaamsopvoeding (Det nationale råd for legemsopdragelse), trykt i tidsskriftet Liggaamsopvoeding, Stellenbosch, april, 1940, s.3-6.

3. Med dette begreb sigtes der på, at et kulturelt fænomen som gymnastik spændes for en direkte politisk vogn, f.eks. når Bukh i 1931 efter turen til Sovjet bruger sin gymnastiske berømmelse til at udbrede antikommunismen i Danmark.

4. Oplysninger om turen uden referencer bygger alle på A. Søgaard Jørgensen, Gennem Sydafrika med Niels Bukh, Kbh., 1940.

5. Kirkegaard, G., Ålborg Stiftstidende, 22/10, 1939.

6. Archer, 1989, s. 35.

7. Jvf. Diem, 1960, s.724f.

8. Jvf. Liggaamsopvoeding, juni, 1939, s.17.

9. Archer, 1982, s.35.

10. Jvf. Diem, 1960, s.725.

11.Jvf. interview med J. Kelder, Cape Town, 1995.

12. Jvf. konvolut påskrevet »Sydafrikaturen«, OA. Der er ingen afrikaanersprogede udklip iblandt, uden tvivl fordi gymnasterne ikke beherskede dette sprog.

13. The Star, 23/9, 1939.

14. Interview med gymnastiklærer Jan Kelder.

15. Generelle oplysninger om sydafrikansk historie,

som i det følgende står uden henvisninger, bygger alle på Davenport, 1991.

16. F.eks. indenfor jernbanerne, læreanstalter og politiet, jvf. Archer, 1981, s.31.

17. Om Broederbond se Hagemann, 1989, s.228ff.

18. SRP 1/2/162 (Undervisningsministeriets rapport for kalenderåret 1939).

19. I de lokale blade annonceredes der efter tilskuere, jvf. The Friend, Bloemfontein, 13/9

20. Jvf. filmen om rejsen.

21. Jvf. Interview med de to deltagere på turen Inger Jølver og Gunver Kirkegaard.

22. Die Suiderstem, 28/8, 1939.

23. Die Burger, 28/8, 1939.

24. Ålborg Stiftstidende, 14/11, 1939.

25. Opvisningen i Seoul i 1931 nåede op på et lignende antal.

26. Jvf. Archer, 1982, op.cit., s.38.

27. Jvf. Liggamsopvoeding, april 1939, s. 56.

28. Jvf. Liggaamsopvoeding, juni, 1939, s. 16.

29. Den kildenære redegørelse for oprustningen af den fysiske kultur i Sydafrika omkring 1939 skyldes, at den er underbetonet i sydafrikansk forskning. En undtagelse er dog Merwes meget faktuelle gennemgang, 1989, s.73-76.

30. Jvf. Sydafrika-filmen.

31. Jvf. Interview med J. Kelder.

32. Furlong, 1991, s. 84f.

33. $26 / 8,1939$.

34. Jvf. Jokl, 1978, s. 61. 
35. Koreografien fremgår af Sydafrika-filmen.

36. Ibid, artiklen »A Nation exercises«, s. 17, 18 og 49 samt nov. 1939, s. $13 \mathrm{f}$.

37. Liggaamsopvoeding, juni 1939, s. 21-26 og september 1939, s.25-34.

38. Jvf. Furlong, 1991, s.5 og Undervisningsministeriets arkivalier i Statsarkivet i Cape Town SRP, 1/2/165, s. 30.

39. Jvf. Boshoff, 1981, s.114 samt interview med J. Kelder.

40. Ålborg Stiftstidende, 19/11, 1939.

41. The Star, 22/9.

42. Bukh regner her næppe de mange millioner ikkeeuropæere med til nationen.

43. Jvf. interview med P.M. Mortensen og »Afrikafilm Plakat«, Olleruparkivet.

44. Jvf. Elevprotokol, Gymnastikhøjskolen i Ollerup, 1930-50, hvori J.Botha angives at være søn af en minister.

45. Undervisningsministeriets rapport for kalenderåret 1940, s. 1 (SRP 1/2/168).

46. Interview med H. Botha samt M.C. Bothas rapport for Undervisningsministeriet i kalenderåret 1938 (SRP 1/2/162).

47. Pellissier var ligesom flere andre af de ledende afrikaanere, som er nævnt her, utvivlsomt medlem af Broederbond. Desværre er der ingen fyldestgørende fortegnelser over medlemmer fra før 1962/63, jvf. Wilkins, 1978, s. A1.

48. Jvf f.eks. interview med Bukh i sydafrikansk radio ved ankomsten til Capetown. Se P.G. Kirkegaards scrapbog, privateje, s. 1.

49. Svendborg Avis, 3/8, 1966.

50. Cape Times 25/8.

51. Så tidligt som i 1911 kan der i det hvide Sydafrika spores en fascination af Grundtvig, andels- og højskolebevægelsen. Rapporten »Biskop Grundtvig og folkehøjskolen i Danmark « var en 38 sider lang rapport til begge parlamentets kamre udgivet på foranledning af undervisningsministeren. Professor J.I. Marais søgte at vise, at »den danske model kunne blive en inspiration for undervisningssystemet og det sydafrikanske landbrug, jvf. Printed Annexures to the votes and proceedings of The house of assembly, Pretoria, 1911, (SRP $1 / 2 / 13)$.

52. Ålborg Stiftstidende, 5/11, 1939.

53. Brev til C.M.C. Leonards, 29/9, 1945.

54. Jvf. også Kirkegaard, G., Ålborg Stiftstidende, 14/11, 1939.

55. Århus Stiftstidende, 4/10, 1939.

56. Jvf. interview med I. Jølver og G. Kirkegaard.
57. Jølver, »Udskrift af breve til mine forældre«, if $\varnothing 1-$ ge brev til forf.

58. Telefoninterview med Søgaards enke.

59. Jvf. Davenport, 1991, s.286.

60. Jvf. Archer, 1982, s. 19.

61. Jvf. Thornton, 1983.

62. Ålborg Stiftstidende, 29/10, 1939.

63. Ålborg Stiftstidende, 5/11, 1939.

64. Ibid, 14/11, 1939.

65. Årsskrift for Gymnastikhøjskolen, Ollerup, 1941, s.103.

66. Niels Bukh i Sydafrika, udateret billedpjece, OA.

67. Furlong, 1989, s.114.

68. Svendborg Avis, 3/8, 1966.

69. Kapitlet om "physical education « bryder i sin begejstrede tone med resten af Undervisningsministeriets rapport for kalenderåret 1938 (SRP 1/2/162). Sandsynligvis har M.C. Botha ladet sønnen J.F. Botha skrive afsnittet. J.F. Botha blev i januar 1941 ansat som Rådets særlige ekspert.

70. Rapporten for 1939 (SRP, 1/2/165).

71. Jvf. interview med H. Botha.

72. Ibid. I lærebogen for drenge, krævedes der mindst 3 timer med gymnastik om ugen. De to øvrige dage anbefaledes sport, jvf. Leerplan vir liggaamlike opvoeding, senior book I, Pretoria, 1947, s.8.

73. Leerplan vir liggaamlike opvoeding, 1947, s.4 samt 1952 (s.2) .

74. Postma, 1968, s.23.

75. (Undervisningsministeriets rapport for kalenderåret, 1938, s. 42 (SRP 1/2/162).

76. Det var Gaulhofer- og Streichergymnastik.

77. Jvf. databasen.

78. Leerplan vir liggaamlike opvoeding, Senior bog, III, Pretoria, 1952, s.2.

79. Transvaal, 20/10, 1939.

80. Jvf. Physical education for boys, Pretoria, 1961, s.IV.

81. Interview med Kelder, ibid og Botha, ibid.

82. Jvf Die Vaderland, 13/2, 1940

83. Gymnasterne Inger Jølver og Gunver Nørskovs scrapbøger (privateje) indeholder især udklip fra Berlingske Tidende, Nationaltidende, BT og Århus Amtsavis.

84. Jvf. »Danske gymnaster sporløst forsvundet«, Nationaltidende, 30/10, 1939.

85. Århus Stiftstidende, december, 1939, udateret.

86. Bukhs pas udstedt 11/6, 1935, s.28.

87. Berlingske Tidende, udateret.

88. Interview med deltageren på turen Haubjerg Mortensen.

89. Årsskrift for Gymnastikhøjskolen, 1939. 
90. Søgaards bog giver også dette indtryk.

91. Interview ved Dr. Storz i Völkische Beobachter, 18/5, 1940. Også refereret i: 'Tyske soldater hos Niels Bukh', artikel i Fædrelandet, 18/5, 1940.

92. Nazisternes dyrkelse af »Völkischkeit« byggede på ideen om, at den arvemæssigt rene tyske befolkning dannede en urkilde, hvoraf staten måtte tage form, men også at den tyske »folkesjæl « fandt sit højeste udtryk via en karismatisk førerskikkelse.

\section{LITTERATUR}

Archer, R. m.fl., The South African Game, London, 1981.

Bonde, H., National Identity and the Body, Scandinavian Journal of History, vol. 20, Kbh., 1994(b), s. 295-314.

Bonde, H., Sport og international politik, Dansk gymnastik i stalinismens gennembrudsfase, Historisk Tidsskrift, Kbh., 1995(c), s. 342-366.

Boshoff, A.L., Die geskiedenis van die departement van liggaamlike opvoedkunde aan die universiteit van Stellenbosch 1936-1975, (upubl. speciale), Stellenbosch, 1981.

Dalen, V.D.B., A World History of Physical Education, New York, 1953.

Davenport, T.R.H., South Africa, A Modern History, London, 1991.

Diem C., Weltgeschichte des Sports und der Leibeserziehung, Stuttgart, 1960.

Furlong P.J., Between Crown and Swastica, The Impact of the Radical Right on the Afrikaner Nationalist Movement in the Fascist Era, Johannesburg, 1991.

Grundlingh, A., Playing for Power? Rugby, afrikaner nationalism and masculinity in south africa, 190070 , The International Journal of the History of Sport, bind. 11, nr. 3, 1994.

Hagemann, A., Südafrika und Das »Dritte Reich«, Rassenpolitische Affinität und Machtpolitische Rivalität, Frankfurt, 1989.

Jones, D., The Emergence of a non-alternative Physical Education for Females in South Africa, ISHPES - Studies, vol. 4, Cape Town, 1995, s.9-23.

Jokl E., Autobiographica, (upubl.), Universitetet i Stellenbosch, 1978.

Jørgensen, A. Søgaard, Gennem Sydafrika med Niels Bukh, Kbh., 1940.
Levi-Strauss, C., Anthropology and Myth, Lectures and Papers, 1951-82, Oxford, 1987.

Nauright, J. (red.), Making Men, Rugby and Masculine Identity, London, 1996.

Paarup-Laursen, N., Liv og forklaring - en analyse af rationalet bag et ritual hos Koma i Nigeria, i: Kulturanalyse -Fortolkningens forløb i antropologien, Kbh., 1989.

Postma, J.W., Introduction to the Theory of Physical Education, Cape Town, 1968.

Thornton, R., Narrative Ethnography in Africa, London, 1983.

Wilkins, I. og Strydom H., The Super-afrikaners, (Broederbond membership list, appendix 1), Johannesburg, 1978.

\section{ARKIVER}

Det Sydafrikanske Undervisningsministeriums Arkiv, Cape Town.

»Olleruparkivet«, Gymnastikhøjskolen i Ollerups arkiv, 1914-1997. Skolens privateje.

\section{INTERVIEWS}

med deltagere fra turen:

Esther Bukh

Helge Jespersen

Inger Jølver

Gunver Kierkegaard

Arne Mortensen

Knud Haubjerg Mortensen,

Peter Meinert Mortensen

Svend Søndergaard

Søgaard Jørgensens enke (telefoninterview). 